\title{
Güvenlik Algısına Etḳi Eden Faktörler Üzerine Bir İnceleme
}

\author{
An Assessment on Factors Affecting Perceived Safety
}

\author{
Can Ozan TUNCER ${ }^{\star}$ - Naci AKDEMİR ${ }^{\star \star}$
}

$\ddot{O} z$

Yapılan çallşmalar güvenlik algısının suç oranlar, yaşanan bölgenin fiziksel ve sosyal özellikleri, kolluk memnuniyeti ve kolluğa duyulan güven ile bireysel farkhlhklar ve sosyal sermaye gibi çeşitli faktörlerden etkilenen kompleks bir kavram olduğunu göstermektedir. Ampirik çalş̧mamızda, ülkemiz alanyazmnndaki güvenlik algısına etki eden faktörler kapsamindaki bilgi açığınn giderilmesine katkı sağlamak maksadıyla, kolluk memnuniyeti, yaşanan çevre memnuniyeti ve suç korkusunun bireylerin güvenlik algısı üzerindeki etkileri incelenmiştir. İcişleri Bakanlı̆̆ İç Güvenlik Stratejileri Dairesi Başkanlğg’nnn yürüttü̈̆̈̈ bir araştırma kapsaminda uygulanan bir anket verisi üzerinde yapilan nicel analiz (Mann-Whitney $U$, Kurskal Wallis $H$ ve Yapisal Essitlik Modeli) yaşanan çeore memnuniyetinin güvenlik algrsı üzerine kolluk memnuniyetinden daha fazla etki ettiğini göstermektedir. Çalı̧mamızn alanyazma bir başka önemli katkısı ise, işlevsel faktörlerin (güvenlik birimlerinin suç önlemede başarll olması ve güvenlik birimlerinin suçu açığa çıkarması) normatif faktörlere (kolluğun nezaketli olması ve polisjandarma personel saynsinin yeterli olmasi) nazaran kolluk memnuniyetine, dolayısiyla güvenlik algisına daha fazla etki ettiğinin tespit edilmesidir.

Anahtar Kelimeler: Güvenlik Algısı, Kolluk Memnuniyeti, Çevresel Faktörler, Güvenlik, Suç Korkusu.

\section{Abstract}

Previous research suggests that the perceived safety is a complex phenomenon affected by various factors such as crime rates, physical and social characteristics of the neighborhood, police satisfaction and trust in law enforcement, individual differences, and social capital. The aim of this study is to address the knowledge gap regarding factors

\footnotetext{
* Dr. Öğr. Üyesi, Yüzüncü Yıl Üniversitesi, Erciş İşletme Fakültesi, Van, Türkiye, ORCID: 0000-0001-9471-4917, e-posta: canozantuncer@gmail.com.

** Dr. Öğr. Üyesi, Jandarma ve Sahil Güvenlik Akademisi, Ankara, Türkiye, ORCID: 0000-0002-4288-6482, e-posta: naci.akdemir@jsga.edu.tr.

Geliş Tarihi / Submitted: 21.02.2021

Kabul Tarihi / Accepted: 16.08.2021
} 
affecting perceived safety by examining the impact of satisfaction on perceived safety in terms of law enforcement satisfaction, neighborhood satisfaction, and fear of crime. The quantitative analysis (Mann-Whitney U, Kurskal Wallis $H$ and Structural Equation Modelling) of a survey conducted in Istanbul suggested that neighborhood satisfaction has a stronger impact on perceived safety when compared to law enforcement satisfaction. Documenting that instrumental factors (success in preventing and combatting crime) affect law enforcement satisfaction more than normative factors (kind treatment by law enforcement and the sufficient number of police-gendarmerie personnel) is another novel contribution of our study.

Keywords: Perceived Safety, Law Enforcement Satisfaction, Environmental Factors, Security, Fear of Crime.

\section{Giriş}

Eski çağlardan beri bireylerin ve toplumların en temel ihtiyaçlarından biri olarak ele alınan güvenlik kavramı Türk Dil Kurumu (TDK) sözlügünde ${ }^{1}$ "toplum yaşaminda yasal düzenin aksamadan yürütülmesi, kişilerin korkusuzca yaşayabilmesi durumu, emniyet" şeklinde ifade edilmiştir. Abraham Harold Maslow'un ihtiyaçlar hiyerarşisinde fizyolojik ihtiyaçların ardından ikinci sırada gelen güvenlik ihtiyacını sırasıyla ait olma ve sevgi, değer ve son olarak kendini gerçekleştirme ihtiyaçları takip etmektedir. Teorinin temelinde bir basamakta yer alan ihtiyaç tamamlanmadan bir diğer basamağa geçilemeyeceği düşüncesi vardır; diğer bir deyişle, bireyin kendini gerçekleştirebilmesi için ilk dört basamaktaki ihtiyaçlarını yeterli düzeyde karşılayabilmesi gerekmektedir. ${ }^{2} \mathrm{Bu}$ anlamda insanların en temel ihtiyaçlarından (fizyolojik ihtiyaçlar) daha kompleks ihtiyaçlara geçişte güvenlik önemli bir yer tutmaktadır. Maslow'un ihtiyaçlar hiyerarşisi bağlamında güvenlik algısı, "bir kişinin en önemli ihtiyaçlarının karşılandiğ ve bu durumun istikrarl kalmasının beklendiği durum" olarak tanımlanabilir. ${ }^{3}$

Güvenlik algısı insanlara korku duymadan özgürce hareket etme ve toplumdaki diğer bireylerle etkileşim kurma olanağı sağlar ve hem sosyal

\footnotetext{
${ }^{1}$ TDK, “Güvenlik”, https://sozluk.gov.tr/, (Erişim tarihi: 15.09.2020).

2 Abrham Harold Maslow, "A Theory of Human Motivation", Psychological Review, 1943, Vol. 50, No. 4, s. 372-380.

${ }^{3}$ Eric Eller ve Dieter Frey, "Psychological Perspectives on Perceived Safety: Social Factors of Feeling Safe", Perceived Safety: A Multidisciplinary Perspective, (Eds. Martina Raue, Bernhard Streicher \& Eva Lermer, Springer, London, 2019, s. 43-60.
} 
hem de ekonomik güvenliği güçlendirmede önemli bir rol oynar. ${ }^{4} \mathrm{Bu}$ durum güvenlik duygusunu sosyal hayatın sürdürülebilirliğinin temel bileşenlerinden biri haline getirir. Tehlike, sosyal düzensizlik veya savaş ve doğal afet gibi nedenlerden dolayı bireylerin fiziksel olarak korunmalarının güç olduğu durumlarda bireyler kişisel güvenlikleri ve korunmaları konusunda derin bir endişe duyarlar. ${ }^{5}$ Güvenlik algısının olumsuz yönde etkilenmesi bireylerin psikolojileri ve sosyalleşme süreçleri üzerinde de önemli etkileri olabilmektedir. ${ }^{6}$ Güvensizlik duygusunun birey tarafından kabul edilebilir sınırları aştığı durumlarda insanlar hayatlarında köklü değişiklikler yapmak zorunda kalabilir. Örneğin, bazı Orta Amerika ülkelerinde yaşanan organize suç örgütleri kaynaklı şiddet olayları, her yıl milyonlarca insanın güvensizlik hissinde yükselişe sebep olmaktadır. Bu durum bu ülkelerde yaşayan vatandaşları taşınmaya, bölge değiştirmeye zorlayan sebeplerden biri olarak gösterilmektedir. ${ }^{7}$

De Donder ve arkadaşlarının güvenlik algısının sadece tek bir faktörden değil, suç oranları, yaşanan bölgenin fiziksel ve sosyal özellikleri, kolluktan memnuniyet, kolluğa güven, bireysel farklılıklar ve sosyal sermaye gibi birçok unsurun bileşkesinden meydana gelen bir olgu olduğunu ortaya koymaktadır. ${ }^{8}$ Bireylerin hayatlarında önemli bir yeri olan güvenlik algısına etki eden faktörlerin tespit edilmesi, kolluğun uygulayacağ 1 suç önleme stratejilerinin belirlenmesi ve uygulanmasının yanı sıra kamu politikalarının geliştirilmesi açısından da önem arz

\footnotetext{
${ }^{4}$ Wesley G. Skogan, "Fear of Crime and Neighborhood Change", Crime and Fustice, 1986, Vol. 8, s. 203-229.

${ }^{5}$ Rosa T. Affleck, Kevin Gardner vd., "Sustainable Infrastructure in Conflict Zones: Police Facilities' Impact on Perception of Safety in Afghan Communities", Sustainability, Vol. 11, No. 7, 2019, 1 - 20, s. 7.

6 Annemarie Ruijsbroek, Mariel Droomers vd., Changes in Area Crime, Area Safety Feelings and the Role of Social Cohesion", Health E Place, Vol. 31, 2015, 39-45, s. 39-45.

${ }^{7}$ David Cantor, "The New Wave: Forced Displacement Caused by Organized Crime in Central America and Mexico", Refugee Survey Quarterly, Vol. 33, 2014, 34-68, s. 49.

${ }^{8}$ Liesbeth De Donder, Nico De Witte vd., "Social Capital and Feelings of Unsafety in Later Life: A Study on the Influence of Social Networks, Place Attachment, and Civic Participation on Perceived Safety in Belgium”, Research on Aging, Vol. 34, No. 4, 2012, s. $425-448$.
} 
etmektedir. ${ }^{9}$ Alanyazında çevresel ve sosyal düzensizliklerin, ${ }^{10}$ kolluk memnuniyetinin,${ }^{11}$ kolluğa duyulan güvenin,${ }^{12}$ sosyal sermayenin ${ }^{13}$ ve suç korkusunun ${ }^{14}$ bireylerin güvenlik algısı üzerindeki etkileri yaygın olarak araştırılmasına rağmen ülkemiz özelinde bu konu hakkında yapılan araştırmalar halen sınırlı düzeydedir.

Ülkemizde yaşanılan çevrenin özellikleri ve suç arasındaki ilişkiyi inceleyen çalışmalar özellikle 1960 'l y yllarda yapılmıştır. Bu alanda yapılan çalışmalara verilebilecek ilk örneklerden biri 1964-1968 yılları arasında Ord. Prof. Dr. Sulhi Dönmezer tarafından yapılmış olan çalışmadır. Ereğli'de gerçekleştirilmiş olan çalışmanın sonucunda Dönmezer söz konusu bölgede suçluluğun artma nedenini sanayileşme ile birlikte gün yüzüne çıkan düzensizlik olarak tanımlamıştır. Söz konusu dönemde Ereğli'de hızlı bir nüfus artışı ve beraberinde konut yetersizliği yaşanmıştır. ${ }^{15}$ Çalışma, kişilerin güvenlik algısını belirlemeye yönelik olmasa dâhi çevresel kriminoloji çerçevesinde ülkemizde yapılan önemli çalışmalardan biri olarak alanyazında yer edinmiştir. Yakın zamanda Bilen ve Büyüklü ${ }^{16}$ tarafından örneklem grubu İstanbul kentinde bulunan sokaklar olan ve

${ }^{9}$ Chris L. Gibson, Jihong Zhao vd., "Social Integration, Individual Perceptions of Collective Efficacy, and Fear of Crime in Three Cities", Fustice Quarterly, Vol. 19, No. 3, 2012, 537-564, s. 537-564.

${ }^{10}$ Joshua C. Hinkle ve Sue-Ming Yang, “A New Look into Broken Windows: What Shapes Individuals' Perceptions of Social Disorder?” Fournal of Criminal Fustice, Vol. 42, No. 1, 2014, 26-35, s. 26-35.

${ }^{11}$ Michael A. Bolger ve Colin P. Bolger, "Predicting Fear of Crime: Results from A Community Survey of A Small City", American Fournal of Criminal Fustice, Vol. 44, No. 2, 2018, 334-351, s. 334-351.

${ }^{12}$ Tammy Rinehart Kochel ve Jacinta Gau, "Examining Police Presence, Tactics, and Engagement as Facilitators of Informal Social Control in High-crime Areas" Fustice Quarterly, 2019, 1-21, s. 1-21.

${ }_{13}$ Susan Clampet-Lundquist, "Everyone Had your Back": Social Ties, Perceived Safety, and Public Housing Relocation, City E Community, Vol. 9, No. 1, 2010, 87-108, s. 87-108.

${ }^{14}$ Joshua C. Hinkle, "Emotional Fear of Crime vs. Perceived Safety and Risk: Implications for Measuring "Fear" and Testing the Broken Windows Thesis", American Fournal of Criminal fustice, Vol. 40, No. 1, 2015, 147-168, s. 147-168.

${ }^{15}$ Sulhi Dönmezer, "Hızla Şehirleşen ve Sanayileşen Bir Küçük Şehir Toplumunda Suçluluk (Ereğli Projesi)", İstanbul Üniversitesi Hukuk Fakültesi Mecmuasi, Cilt: 39, Sayı: 1-4, 1974, 1-75, s. 1-75.

${ }^{16}$ Omer Bilen ve Ali Hakan Büyüklü, “Kırık Pencereler Teorisi’nin İstanbul Metropoliten Alanı'nda Geçerliliğinin Testi”, Iddealkent, Cilt: 9, Sayı: 23, 2018, 160-188, s.160-188. 
Kırık Camlar Suç Modeli ${ }^{17}$ kullanılarak yapılan çalışmada çevre tasarımının güven duygusu üzerinde olumlu yönde etkisi olduğu sonucuna varılmıştır. Benzer şekilde, Arpa ve Uğurlar ${ }^{18}$ Van ilinde suç ve mekân bağlamında güvenlik algısını incelemek üzere gerçekleştirdikleri çalışmada, çevresel tasarımın ve kent planlamalarının, güvensizlik duygusunu önlemede önemli etkiye sahip olduğunu ortaya koymuştur.

$\mathrm{Bu}$ çalışmada ülkemiz alanyazınındaki güvenlik algısına etki eden faktörler kapsamındaki bilgi açığının giderilmesine katkı sağlamak maksadıyla, kolluk (jandarma ve polis) memnuniyeti, yaşanan çevre memnuniyeti ve suç korkusunun bireylerin güvenlik algısı üzerindeki etkileri incelenmiştir. Temel araştırma sorumuz olan "güvenlik algısına etki eden faktörler nelerdir?" sorusuna yanıt bulabilmek ve geliştirilen hipotezleri test etmek amacıyla, İçişleri Bakanlığı İç Güvenlik Stratejileri Dairesi Başkanlığı'nın yürüttüğü bir araştırma kapsamında İstanbul ili Bağcılar ilçesinde ikamet eden vatandaşlara uygulanan bir anket verisi, alınan izin neticesinde nicel analize "Mann-Whitney U, Kurskal Wallis H ve Yapısal Eşitlik Modeli" tabi tutulmuştur.

\section{Güven Algısına Etki Eden Faktörler}

\subsection{Kolluk Memmuniyeti, Kolluğa Duyulan Güven ve Kolluk Meşruiyeti}

Yakında dönemde yapılan araştırmalar emniyet ve asayişin sağlanması ile görevli kolluk kuvvetlerine duyulan güven ve memnuniyetin bireylerin yaşam kalitesi ve güvenlik duygusu üzerinde önemli etkileri olduğunu göstermektedir. ${ }^{19}$ Kolluğa duyulan memnuniyetle ilgili çalışmalar, memnuniyet algısının yaşanılan bölgenin özellikleri (suç oranları, alt kültür gruplarının varlığı veya çöplerin toplanması gibi), bireylerin kollukla daha önce yaşadığı deneyimler ve bireysel özelliklerinden (ırk, yaş ve cinsiyet)

17 Kırık Camlar Suç Modeli sosyal ve çevresel düzensizliklerin bireylerin suç ve güvenlik algısı üzerinde etkili olduğunu ön görmektedir. Bu model sosyal ve çevresel düzensizliklerin ortadan kaldırılması yoluyla suç ve suçlulukla etkili mücadele edilebileceğini ileri sürmektedir.

${ }^{18}$ Esra Arpa ve Aysu Uğurlar, "Suç ve Mekan Bağlaminda Güven Alg1sı: Van Örneği”, Yüzüncü Yıl Üniversitesi Sosyal Bilimler Enstitüsü Dergisi, Cilt: 44, 2019, 293-323, s. 293-323.

${ }^{19}$ Bolger, a.g.e., Rinehart, Gau, a.g.e. 
etkilendiğini ortaya koymaktadır. ${ }^{20}$ Kolluk memnuniyeti ve kolluğa duyulan güven kolluk meşruiyetinin en önemli bileşenleridir. ${ }^{21}$ "Yasal otoritelerin itaat edilme hakkına sahip olduğu ve bireylerin bu otoritelerin kararlarna saygı duymalar gerektiğini" 22 ifade eden meşruiyet kavramı, kolluğun vatandaşlarla uyum ve iş birliği geliştirmesinde etkin bir faktördür. ${ }^{23}$ Kolluk meşruiyetini geliştirmeyi amaçlayan kolluk yaklaşımlarından birisi olan Usul Adalet Kolluğu yaklaşımı, bireylerin kolluk algısı üzerinde, kolluğun elde ettiği sonuçlar kadar bu sonuçlara da nasıl ulaştığının önemli olduğunu savunur. ${ }^{24}$ Usul adaleti yaklaşımı, bireylerin yetkililer tarafından maruz kaldıkları muameleye önem verdiklerini ve bu makamlarca verilen emirlere uyma kararının gördükleri muameleden önemli ölçüde etkilendiğini ileri sürer. ${ }^{25}$ Usul adalet kolluğu yaklaşımı, kolluğun yaptırım ve zor kullanma yetkisini kullanırken tarafsız olması, kabul edilebilir gerekçeler ortaya koyması, saygılı davranması ve vatandaşlara kendilerini ifade etme şansı vermesi esasları üzerine kurulmuştur. ${ }^{26}$ Örneğin, kolluğun trafik uygulamaları esnasındaki hareket tarzlarının bireylerin kolluk algısı üzerindeki etkilerini inceleyen çalışmalar, sürücülerin cezai bir yaptırıma uğramalarından ziyade kolluğun yaklaşımına daha önem verdiklerini ortaya koymaktadır. ${ }^{27}$ Benzer şekilde, Gau, Corsaro, Stewart, and Brunson'un ${ }^{28}$ kolluk meşruiyetinin yordayıcıları

\footnotetext{
${ }^{20}$ James Frank, Brad W. Smith vd., "Exploring the Basis of Citizens' Attitudes toward the Police”, Police quarterly, Vol. 8, No. 2, 2015, 206-228, s. 206-228.

${ }^{21}$ Justice Tankebe, "Viewing Things Differently: The Dimensions of Public Perceptions of Police Legitimacy”, Criminology, Vol. 51, No. 1, 2013, 103-135, s. 103-135.

${ }^{22}$ Tom R. Tyler ve Yuen Huo, Trust in the Law: Encouraging Public Cooperation with the Police and Courts, Russell Sage Foundation, New York, 2002, s. 14.

${ }^{23}$ Lorraine Mazerolle, Emma Antrobus vd., "Shaping Citizen Perceptions of Police Legitimacy: A Randomized Field Trial of Procedural Justice”, Criminology, Vol. 51, No. 1, 2013, 33-63, s. 33-63.

${ }^{24}$ Tom R. Tyler, Why People Obey the Law, Princeton University Press, Princeton, N.J., 2006.

${ }^{25}$ Jason Sunshine. ve Tom R. Tyler, "The Role of Procedural Justice and Legitimacy in Shaping Public Support for Policing", Law E Society Review, Vol. 37, No. 3, 2003, 513-548, s. 513-548.

${ }^{26}$ Julie M. Barkworth ve Kristina Murphy, "Procedural Justice Policing and Citizen Compliance Behaviour: The Importance of Emotion", Psychology, Crime E Law, Vol. 21, No. 3, 2015, 254-273, s. 254-273.

${ }^{27}$ Richard Johnson, "Citizen Expectations of Police Traffic Stop Behavior.” Policing, Vol. 27, 2004, s. 487-497.

${ }^{28}$ Jacinta M. Gau, Nicholas Corsaro vd., "Examining Macro-Level Impacts on Procedural
} 
üzerine yaptığı çalışma, sosyo-ekonomik ve çevresel faktörler kontrol edildiğinde dahi usul adaletinin kolluk meşruiyetinin oluşmasında en güçlü etmen olduğunu ortaya koymuştur.

Suç, insanların kentsel mekânlarla ilgili değerlerini ve algılarını değiştiren ve bir şehrin sakinlerinin yaşam kalitesini tehlikeye atan mekânsal bir çarpan etkisine sahiptir. ${ }^{29} \mathrm{Bu}$ bağlamda, geçmiş araştırmalar kolluğun suç önleme ve suçla mücadelesinin, vatandaşların kolluk memnuniyetini, dolayısıyla güvenlik algısını olumlu yönde etkilediğini göstermiştir. ${ }^{30}$ Örneğin, Nofziger and Williams'ın ${ }^{31} 301$ katılımcıyla telefon mülakatı neticesinde yapmış olduğu araştırma sonucuna göre kolluk memnuniyeti kolluğun suçla mücadelesindeki etkinliğinden, güvenlik alg1sı ile kolluk memnuniyetinden etkilenmektedir. Fakat Ratcliffe, Groff, Sorg, and Haberman ${ }^{32}$ Filedelfiya kolluk taktikleri deneyi kapsamında yaptıkları çalışma, kolluğun suçu azaltma gayretlerinin (yaya devriyeler, suçlu odaklı kolluk ve problem odaklı kolluk uygulamaları) topluluğun kolluk memnuniyeti ve güvenlik algısı üzerinde kayda değer bir etkisinin bulunmadığını ortaya koymuştur. Bu çalışmada uygulanan iki kolluk stratejisi (suçlu odaklı kolluk ve problem odaklı kolluk) toplumda suç işleme riski olan kişileri hedef aldığından bu kişilerin aileleri, arkadaşları ve yakınları haksız bir uygulamaya tabi tutulduklarını düşünebileceklerinden kolluk memnuniyetinde bir artış gözlenmemesi sonucunu doğurmuş olabilir. Ancak suçlu odaklı kolluk ve problem odaklı kolluk uygulamalarına yöneltilen en önemli eleştiri de bu kolluk stratejilerinin kolluğun

Justice and Police Legitimacy", Fournal of Criminal Fustice, Vol. 40, No. 4, 2012, 333-343, s. 333-343.

${ }^{29}$ Akenya Alkimim, Keith K. Clarke vd., "Fear, Crime, and Space: The Case of Viçosa, Brazil", Applied Geography, Vol. 42, 2013, 124-132, s. 124.

${ }^{30}$ Jonathan Jackson, Ben Bradford vd., Fust Authority?: Trust in the Police in England and Wales, Routledge 2012.; Jose Alexis Torres, "Predicting Perceived Police Effectiveness in Public Housing: Police Contact, Police Trust, and Police Responsiveness", Policing and Society, Vol. 27, No. 4, 2017, 439-459, s. 439-459.

${ }^{31}$ Stacey Nofziger ve Susan Williams, "Perceptions of Police and Safety in a Small Town”, Police quarterly, Vol. 8, No. 2, 2005, 248-270, s. 248-270.

${ }^{32}$ Jerry H. Ratcliffe, Elizabeth R. Groff, vd., "Citizens' Reactions to Hot Spots Policing: Impacts on Perceptions of Crime, Disorder, Safety and Police", Fournal of Experimental Criminology, Vol. 11, No. 3, 2015, 393-417, s. 393-417. 
meşruiyetine zarar verebileceği yönündedir. ${ }^{33}$ Reid, Appleby-Arnold, Brockdorff, Jakovljev ve Zdravković'in ${ }^{34}$ yaptıkları çalışmanın sonuçları da suç oranı yüksek olan bölgelerde yaşayan bireylerin kolluğa duydukları güvenin suç oranı düşük olan bölgelerde yaşayanlara göre daha düşük olduğu yönündedir. Bu sonuç kolluk memnuniyetinin ve güvenlik algısının farklı bir bağlamda değerlendirilmemesi gerektiğini gözler önüne sermektedir.

Kolluğun varlığı ve güven algısı arasındaki ilişki alanyazında çelişkili sonuçlar veren bir başka husustur. Kelling'in 1990 yılında yaptığı bir çalışma devriye hizmetlerinin vatandaşların suç korkularını anlamlı bir biçimde azalttığını, devriye hizmetlerinin bulundukları bölgeden çekilmesi sonucunda ise suç korkularının belirgin bir biçimde arttığını ortaya koymaktadır. Kolluktan memnun olma duygusunun da yine devriyelerin artışıyla paralel bir şekilde arttığı görülmüştür. ${ }^{35}$ Bir başka çalışmada ise üniformalı personelin insanların kendilerini güvende hissetmesine etki edip etmediği üzerine yoğunlaşılmıştır. Hinkle ve Weisburd ${ }^{36}$ yaptıkları çalışmanın sonucunda bireylerin kolluğun kontrolü sağlayabildiğini ve gerekli durumlara müdahale ettiğini görmeleri durumunda güven duygularının arttığını ortaya koymuştur. Fakat Hill, Pollet, and Nettle ${ }^{37}$ tarafından yapılan çalışma polisin varlığı ile güven duygusu arasında bir ilişkinin bulunmadığını tespit etmiştir. Kolluğun bir bölgedeki varlığı ve güven algısı arasındaki ilişkileri inceleyen bahsi geçen araştırma sonuçları arasındaki çelişkilerin nedenlerinden birisinin bölgedeki suç oranları olduğunu söylemek mümkündür. Suç yoğun bölgelerde resmî üniformalı kolluğun varlığı bireylerin kendilerini daha fazla güvende hissetmelerine

33 Tammy Rinehart Kochel, "Constructing Hot Spots Policing: Unexamined Consequences for Disadvantaged Populations and for Police Legitimacy", Criminal Fustice Policy Review, Vol. 22, No. 3, 2011, 350-374, s. 350-374.

34 Iain D. Douglas Reid, Sandra Appleby-Arnold vd.' "Developing a Model of Perceptions of Security and Insecurity in the Context of Crime", Psychiatry, Psychology and Law, Vol. 27, No. 4, 2020, 620 -636, s. 620 -636.

${ }^{35}$ George Kelling, Foot Patrol, Crime File. Study Guide, National Institute of Justice, US Department of Justice, Washington DC, 2009.

${ }^{36}$ Joshua C. Hinkle ve David Weisburd, "The Irony of Broken Windows Policing: A Micro-Place Study of the Relationship between Disorder, Focused Police Crackdowns and Fear of Crime", Fournal of Criminal Fustice, Vol. 36, 2008, 503-512, s. 503-512.

${ }^{37}$ Jessica Hill, Thomas Pollet vd., "Disorder Affects Judgements about a Neighbourhood: Police Presence Does Not” Peerf,2014, Vol. 2, No. 1, 1-18, s. 1-18. 
yol açtığı düşünülebilir. Nitekim Van de Veer, de Lange, van der Haar, and Karremans $^{38}$ tarafından yapılan araştırma kolluğun varlığının suç yoğunluğunun yüksek olduğu bölgelerde güvenlik hissini arttırdığını, suç yoğunluğunun düşük olduğu bölgelerde ise kolluğun varlığının bireylerin güvenlik algılarını düşürdüğünü tespit etmiştir. Güven algısı ölçülen bölgelerde alt kültür gruplarının varlığı da, kolluğun görünürlüğü ve güven algısı arasındaki ilişki üzerinde etkileri olabilmektedir. Örneğin, ABD'de kolluk tarafından ön yargılı uygulamalara maruz kaldığına inanan alt kültür grupları, kolluk personelinin bulunduğu ortamlarda kendilerini daha az güvende hissettiklerini ifade etmiştir. ${ }^{39}$

\section{2 Çevre Memnuniyeti ve Güvenlik Algisı}

Güvenlik, kamusal alanların kalitesini ve çekiciliğini belirlemede en önemli faktörlerden biri olarak görülmektedir. Bunun nedeni bir bireyin bir alanın güvenliğini algılamasının, onun söz konusu alanı kullanma veya oradan kaçınma kararında güçlü bir etkiye sahip olmasıdır. ${ }^{40} \mathrm{Bu}$ özellik insan doğasında var olan ve atalarından genler aracılığıyla devraldığı hayatta kalma hissi ile yakından alakalıdır. ${ }^{41}$ Appleton $^{42}$ estetik özelliklerin yanı sıra yeme içme ve barınma gibi biyolojik ihtiyaçları karşılayan alanların içgüdüsel olarak insanlara daha güven verici geldiğini ifade etmektedir. $\mathrm{Bu}$ bağlamda, çevre koşullarının ve bireylerin çevrelerine karşı duydukları memnuniyetin yaşam kalitesini belirlemede kayda değer bir önemi vardır. Nitekim araştırmalar gelişen dünyada mekânsal faktörlerin güvenlik algısına etkisinin giderek arttığını göstermektedir. ${ }^{43}$

\footnotetext{
${ }^{38}$ Evelien van de Veer, Martijn A. de Lange vd., “ Fournal of Applied Social Psychology, Vol. 42, No. 12, 2012, 3114-3125, s. 3114-3125.

${ }^{39}$ Michael D. Reisig ve Roger B. Parks, "Satisfaction with Police - What matters?" US Department of Fustice, Washington, DC, 2002.

${ }^{40}$ Vikas Mehta, "Evaluating Public Space", fournal of Urban Design, Vol. 19, No. 1, 2014, 53-88, s. 60.

${ }^{41}$ Laura J. Loewen, Gary Daniel Steel vd., "Perceived Safety fromCcrime in the Urban Environment”, Fournal of Environmental Psychology, Vol. 13, No. 4, 1993, 323-331, s. $323-331$.

${ }^{42}$ Jay Appleton, The Experience of Landscape, Wiley, New York, 1996.

${ }^{43}$ Hinkle, a.g.e.; Rebecca Miles, "Neighborhood Disorder, Perceived Safety, and Readiness to Encourage Use of Local Playgrounds", American Fournal of Preventive Medicine, Vol. 34, No. 4, 2008, 275-281, s. 275-281; Jerry Ratcliffe, Elizabeth Groff, vd., a.g.e.
} 
$\mathrm{Bu}$ perspektif kamusal alanda görülen küçük fiziksel ve sosyal düzensizliklerin bireyleri daha ciddi suçlar işlemek için cesaretlendireceğini ve düzensizliklerin bireylerde suç korkusunu arttıracağ $1 n 1^{44}$ öne sürmektedir. $\mathrm{Bu}$ özelliği ile bu yaklaşım çevresel faktörlerin suç ve suç korkusu üzerindeki etkilerini inceleyen çalışmalara kaynaklık teşkil etmiştir. Örneğin, Hinkle; ${ }^{45}$ duvar yazıları, terk edilmiş veya yıkılmaya yüz tutmuş binalar gibi çevresel düzensizliklerin güvenlik algısını olumsuz yönde etkilediğini ve algılanan riski arttırdığını ortaya koymaktadır. Bir başka çalışma ise, çevre temizliği, yeşillendirme çalışmaları ve çevresel iyileştirme faaliyetlerinin (parklar, spor salonları ve koşu parkurlarının açılması) bireylerin güvenlik algıları üzerinde olumlu katkıları olduğunu ortaya koymuştur. ${ }^{46}$ Benzer şekilde Lapham ${ }^{47}$ yaptığı çalışma parklarda yapılan fiziksel iyileştirmelerin bölge sakinlerinin güvenlik algısında kayda değer derecede bir artışa neden olduğunu tespit etmiştir.

\subsection{Suç Korkusu ve Güvenlik Algısı İlişkisi}

İlk olarak 1960lı yıllarda Amerika Birleşik Devletleri'nde yoğun olarak ilgi görmeye başlayan ve zaman içerisinde farklı ülkelerde de birçok araştırmaya konu olan suç korkusu kavramı hem akademisyenlerin hem de kolluk kuvvetlerinin yakından takip ettiği bir konu haline gelmiştir. ${ }^{48}$ Alanyazında farklı tanımları mevcut olan kavram temelde "bir suça maruz kalma riski algısının sonucu olarak ortaya çıkan bir duygu” olarak açıklanmaktadır. ${ }^{49}$ Ferraro $^{50}$ ise, suç korkusunu "suça ya da kişinin suçla ilişkilendirdiği sembollere karşı geliştirdiği endişe veya duygusal tepki” olarak

\footnotetext{
44 James Q.Wilson ve George L. Kelling, "Broken windows: The Police and Neighborhood Safety”, Atlantic Monthly, Vol. 211, 1982, 29-38, s. 29-38.

${ }^{45}$ Hinkle, a.g.e.

${ }^{46}$ Bin Jiang, Cecilia Nga Sze Mak vd., From Broken Windows to Perceived Routine Activities: Examining Impacts of Environmental Interventions on Perceived Safety of Urban Alleys", Frontiers in Psychology, Vol. 9, 2018, 2450.

${ }^{47}$ Sandra Lapham, Deborah Cohen vd., "How important is Perception of Safety to Park Use? A four-city Survey", Urban studies, Vol. 53, No. 12, 2016, 2624-2636, s. 2624-2636.

${ }^{48}$ Chris Hale, "Fear of Crime: A Review of the Literature", International Review of Victimology, Vol. 4, 1996, 79-150, s. 79

${ }^{49}$ Rafael Prieto Curiel and Steven Bishop, "Modelling the Fear of Crime”, Proceedings of the Royal Society, No. 473, 2017, 1-14, s.1.

${ }^{50}$ Kenneth F. Ferraro, Fear of crime: Interpreting Victimization Risk, State University of New York Press, Albany, 1995, s. 4.
} 
tanımlamıştır. Suç korkusuna dair iki tanım karşılaştırıldığında, ilk tanım daha çok algılanan riske vurgu yaparken, ikinci tanım korkunun duygusal boyutunu ön plana çıkarmaktadır. Son dönemde alanyazında algılanan risk ile suç korkusunu birbirinden ayırma eğilimi vardır. ${ }^{51}$ Bunun temel nedeni ise, algılanan riskin daha çok bir suçun mağduru olma riski üzerine bireylerin yapmış olduğu bilişsel bir değerlendirme iken, suç korkusunun tehlikelere karşı duygusal bir reaksiyon olmasıdır. ${ }^{52}$

Ayrıca, Skogan ${ }^{53}$ suç korkusunu yalnızca bireysel düzeyde değil toplumsal düzeyde de ciddi olumsuz sonuçlar doğurabilecek bir olgu olarak ele almıştır. Bu yaklaşıma göre suç korkusu altı aşamalı bir sürecin sonucunda toplumda çöküşe sebebiyet verebilecek bir duygudur. Skogan bu aşamaları toplumsal yaşamdan fiziksel ve psikolojik olarak geri çekilme, informal sosyal kontrolün zayıflaması sonucu suç ve düzensizlikte artış yaşanması, yaşanılan çevredeki örgütlü yaşam ve mobilizasyon kapasitesinde düşüş, kötüye giden iş koşulları, toplumda farklı suç ve sapma kavramlarının yerleşmesi ve toplum yapısında önemli değişiklikler meydana gelmesi olarak ele almaktadır. ${ }^{54}$ Winkel $^{55}$ ise suç korkusunu iki ana etkene dayandırmış; kişisel mağduriyet riski ve algılanan olumsuz etkinin kendisinin korkuyu artırdığını ileri sürmüştür. Suç korkusunu deneyimleyen bir birey temel olarak kendisinin ya da bir yakınının bir suça maruz kalma ihtimalinden kaynaklanan bir korku hissetmektedir. Söz konusu korku yalnızca suça maruz kalınan anla ilişkili değildir; bu korku aslen muhtemel bir mağduriyeti takiben gün yüzüne çıkması olası problemlerden kaynaklı olarak, kişinin kendisini içinde bulacağı uyum sürecini de hesaba katarak daha ileri düzeyde bir his olarak karşımıza çıkar. ${ }^{56}$

51 Randy LaGrange ve Kenneth Ferraro, "Assessing Age and Gender Differences in Perceived Risk and Fear of Crime”, Criminology, Vol. 27, No. 4, 1989, 697-720, s. 697-720.

${ }^{52}$ Andres F. Rengifo ve Amanda Bolton, "Routine Activities and Fear of Crime: Specifying Individual-level Mechanisms", European Fournal of Criminology, Vol. 9, No. 2, 2012, 99-119, s. 99-119.

${ }^{53}$ Skogan, a.g.e., s. 215.

${ }^{54}$ A.e.

${ }^{55}$ Frans Willem Winkel, "Fear of Crime and Criminal Victimization: Testing a Theory of Psychological Incapacitation of the "Stressor" Based on Downward Comparison Processes”, British Fournal of Criminology, Vol. 38, No. 3, 1998, 473-484, s. 474.

${ }^{56}$ Mualla Köseoğlu ve Tülin İçli "Kadınlarda Suç Korkusunun Çeşitli Değişkenler Açısından Değerlendirilmesi: Kuzey Kıbrıs örneği”, Sosyal Politika Çalışmaları Dergisi, 
Diğer yandan, suç korkusu ile güvenlik algısı da alanyazında sıkça birbirine karıştırılan kavramlardır. ${ }^{57}$ Güvenlik algısı genel olarak "bir kişinin en önemli ihtiyaçlarının karşılandiğı ve bu durumun istikrarlı kalmasının beklendiği durum" olarak tanımlanabilir. ${ }^{58} \mathrm{Bu}$ bağlamda güvensizlik algısı, bireysel güvenliğe ve sağllğa, beden bütünlüğüne yönelik tehditleri kapsayabileceği gibi suç ve düzensizlik gibi durumlarda da ortaya çıkabilir. Güvenlik algısı bireylerin algıları ile bağlantılı olduğu için sübjektiftir ve çoğunlukla bireylerin bir yargıya varmasını veya karar vermesini gerektiren durumlarla yakından ilgilidir. Bir başka deyişle hadiselerin cereyan ettiği bağlamdan etkilenir. ${ }^{59}$ Güvenlik algısı bir boyutu ile suç korkusunu (tehlikeye karşı duyulan duygusal reaksiyonu) ve bir diğer boyutu ile de algılanan riski (bilişsel boyutu) kapsamaktadır. Şunu da eklemek gerekir ki, güvenlik algısı suç oranları gibi istatistiki verilerden ziyade bireylerin olayları bulundukları bağlamda nasıl yorumladıkları ile daha yakın ilişkilidir. ${ }^{60}$

\section{Amaç ve Yöntem}

Bireylerin güvenlik algısını etkileyen faktörlerin belirlenmesi amaciyla çevre memnuniyetinin, kolluk memnuniyeti ve suç korkusunun bireylerin güvenlik algıları üzerine olan etkileri araştırılmıştır. Bu amaçla İçişleri Bakanlığınca yürütülen bir araştırma kapsamında toplanmış olan ilgili verilerden bu araştırma için ihtiyaç duyulanlar analize tabi tutulmuştur. Veri setinin kullanılabilmesi maksadıyla kurumsal onay alınmıştır. Araştırma kapsamında İstanbul ili Bağcılar ilçesinde ikamet eden 18 yaş üstü 1567 kişiye tesadüfi örnekleme yoluyla 01 Ağustos 2020 ile 31 Ağustos 2020 tarihleri arasında anket çalışması yapılmıştır. Anket çalışması sonucunda elde edilen verilerle IBM SPSS nicel analiz programı ve IBM SPSS AMOS 26 Graphics programları vasitasıly betimsel ve

Cilt: 19, Say1: 43, 2019, 267- 296, s. 269-270.

57 Hinkle, a.g.e.; Mark Warr, "Fear of Crime in the United States: Avenues for Research and Policy", Criminal fustice, Vol. 4, No.1, 2000, 451-489, s. 451-489.

${ }^{58}$ Eller and Frey, a.g.e., s. 44.

${ }^{59}$ Martina Raue and Elisabeth Schneider, "Psychological Perspectives on Perceived Safety: Zero-Risk Bias, Feelings and Learned Carelessness", Perceived Safety: A Multidisciplinary Perspective, (Eds. Martina Raue, Bernhard Streicher \& Eva Lermer), Springer, London, 2019, 61-81, s. 61-81.

${ }^{60}$ Eller ve Frey, a.g.e.; Raue and Schneider, a.g.e. 
çok değişkenli (Mann-Whitney $\mathrm{U}$ ve Kruskal Wallis $\mathrm{H}$ testleri ile doğrulayıcı faktör analizi ve yapısal eşitlik modeli) analizler yapılmıştır.

Yapısal eşitlik modeli, regresyon analizleri ile kurulması imkânsız olan modeller vasıtasıyla örtük (gözlemlenemeyen) değişkenler ve gözlemlenen değişkenler arasındaki ilişkileri inceleyen bir analiz yöntemidir. ${ }^{61}$ Birden fazla regresyon analizini (yol analizi) ve faktör analizlerini tek bir model içerisinde ifade etmesi ve değişkenler arasındaki karmaşık ilişkileri görsel bir modelleme ile sunması nedeniyle yapısal eşitlik modeli başta sosyal bilimler olmak üzere psikoloji, işletme, biyoloji ve pazarlama gibi pek çok alanda yaygın olarak kullanılmasını sağlamıştır. ${ }^{62}$ Değişkenler arasındaki ilişkileri incelerken hata terimlerini de dikkate alması yapısal eşitlik modelinin tercih edilme nedenlerinden birisidir. ${ }^{63}$

\subsection{Dışsal (Bă̆ımsız) Değisskenler}

Araştırma modelinde yer alan diğer değişkenleri yordayan (tahminde bulunmamızı sağlayan) veya açıklayan değişkenlerdir.

Çevre Memnuniyeti: Araştırmada yer alan çevresel faktörler bir örtük değişkendir. Örtük değişkenler araştırmacı tarafından doğrudan ölçülemeyen zekâ, mutluluk veya korku gibi değişkenlerdir. Kırık camlar teorisi çevresel ve sosyal düzensizliklerin doğrudan güvenlik kaygılarını arttıracağını, dolaylı olarak da suçun artmasına neden olacağını öne sürmektedir. ${ }^{64}$ Katılımcıların çevresel faktörler ile ilgili algıları örtük değişken olduğu için, bu kavram beş adet gösterge (gözlenen) değişken ile ölçülmüştür. Bireylerin yaşadıkları ilçe ile ilgili görüşlerini beşli-Likert ölçeği ile ölçen değişkenler Tablo-l'de sunulmuştur.

\footnotetext{
${ }^{61}$ Jodie B. Ullman and Peter M. Bentler "Structural Equation Modeling", Handbook of Psychology, 2003, 607-634, s. 607-634.

62 Barbara M. Byrne, Structural Equation Modeling with AMOS: Basic Concepts, Applications, and Programming, Routledge, New York, 2016.

${ }^{63}$ Kristopher Preacher, Zhen Zhang vd.,"Alternative Methods for Assessing Mediation in Multilevel Data: The Advantages of Multilevel SEM", Structural Equation Modeling, 2011, Vol. 18, No. 2, 161-182, s. 161-182.

${ }^{64}$ Jacinta M. Gau ve Travis Pratt, "Revisiting Broken Windows Theory: Examining the Sources of the Discriminant Validity of Perceived Disorder and Crime", fournal of Criminal Fustice, Vol. 38, No. 4, 2010, 758-766, s. 758-766.
} 
Kolluk Memnuniyeti (Fandarma ve Polis): Kolluk memnuniyeti Warner and Burchfield ${ }^{65}$ tarafından üç madde (kolluk suç önlemede önemli bir rol üstlenmektedir, kolluk suç sonrası suç mağdurlarının ihtiyaçlarına karşılık vermede başarılıdır ve kolluk vatandaşla iletişiminde yardımseverdir) ile ölçülmüştür. Araştırmamızda, bu ölçekten istifade edilerek, katılımcıların güvenlik kurumları hakkındaki memnuniyetleri kendi bölgelerinden yer alan kolluk personel sayıları, kolluk personelinin nezaketi, kolluğun suç önlemedeki başarısı, suçları açığa çıkarmadaki yeterliliği ve uyuşturucu madde ile mücadeledeki başarısı olmak üzere beş gösterge (gözlenen) değişken ile ölçülmüştür.

Suç Korkusu: Bireylerin belirli suçlara karşı duydukları kaygı düzeyleri ikili ölçek ile $0=$ kaygının yokluğu $1=$ kaygının varlığı şeklinde ölçülmüştür. Bu bölümde dokuz suç türüne karşı duyulan korku ile güvenlik hissi arasındaki ilişkiler incelenmiştir. Dışsal değişkenler Tablo-l'de sunulmuştur.

\section{2 İçsel (Bă̆ımlı) Değişken}

Yapısal eşitlik modelinde yer alan diğer değişkenler tarafında yordanan değişkenlere verilen addır. Rinehart Kochel ve Gau Rinehart ${ }^{66}$ güvenlik algısını "evdeyken evin kapılarını kilitlememek, gün içerisinde yalnız yürümek, gece yalnız başına yürümek ve gece evde kalmak olmak üzere dört değişken ile ölçmüştür. Araştırmamızda örtük değişken olan güvenlik algısı dört adet gözlemlenen değişken ile ölçülmüştür (gece yalnız başıma sokağa çıkmakta bir tedirginlik görmüyorum, çocuklarım parkta oynarken tedirgin olmuyorum, arabamı sokağıma park ettiğimde bir tedirginlik hissetmiyorum, bir kadın mahallede istediği saatte güvenli bir şekilde yürüyebilir). Güvenlik ölçeğinde yer alan gözlenen değişkenler beşli-Likert ölçeği ile ölçülmüştür.

\subsection{Hipotezler}

Çevre memnuniyeti, kolluk memnuniyeti ve suç korkusunun bireylerin güvenlik algısı üzerindeki etkilerini araştırmak maksadıyla alan

\footnotetext{
${ }^{65}$ Barbara D. Warner ve Keri Burchfield, "Misperceived Neighborhood Values and Informal Social Control”, fustice Quarterly, Vol. 28, No. 4, 2011, 606-630, s. 606-630.

${ }^{66}$ Rinehart Kochel ve Gau, a.g.e.
} 
taraması bölümünde açıklanan teoriler ve geçmiş yıllardaki araştırma sonuçları esas alınarak aşağıdaki hipotezler geliştirilmiştir.

H1: Bireylerin çevreleri ile ilgili olumlu algıları ve güvenlik algıları arasında istatistiksel olarak anlamlı pozitif bir ilişki vardır.

H2: Bireylerin kolluk kuvvetlerine (Jandarma ve Polis) duydukları memnuniyet ile güvenlik algıları arasında istatistiksel olarak anlamlı pozitif bir ilişki vardır.

H3: Bireylerin suç korkusu ile güvenlik algıları arasında istatistiksel olarak anlamlı negatif bir ilişki vardır.

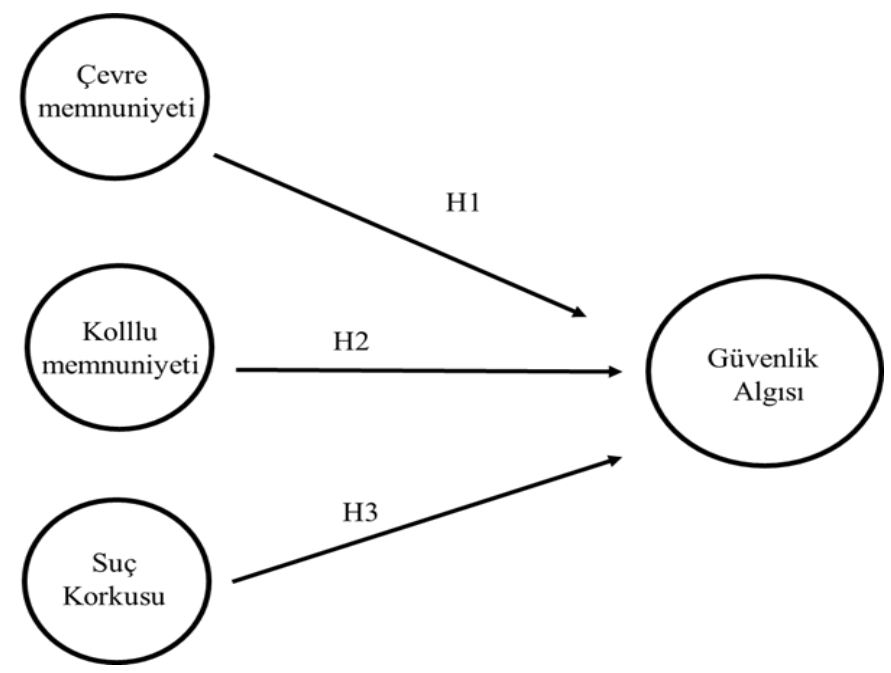

Şekil 1. Araştırma Modeli ${ }^{67}$

${ }^{67}$ İlgili şekil yazarlar tarafından oluşturulmuştur. 
Tablo 1. İçsel ve Dişsal Değişkenler ${ }^{68}(\mathrm{~N}=1567)$

\begin{tabular}{|c|c|}
\hline Değişkenler & Ölçüm Aralığ \\
\hline \multicolumn{2}{|l|}{ İçsel } \\
\hline \multicolumn{2}{|l|}{ Güvenlik Algis1 } \\
\hline Gece yalnız başıma sokağa çıkmakta bir tedirginlik görmüyorum & $1-5$ \\
\hline Çocuklarım parkta oynarken tedirgin olmuyorum & $1-5$ \\
\hline Arabamı sokağıma park ettiğimde bir tedirginlik hissetmiyorum & $1-5$ \\
\hline Bir kadın mahallede istediği saatte güvenli bir şekilde yürüyebilir & $1-5$ \\
\hline \multicolumn{2}{|l|}{ Dışsal } \\
\hline \multicolumn{2}{|l|}{ Çevre Memnuniyeti } \\
\hline Çocuk büyütmek için uygun bir yerde yaşıyorum & $1-5$ \\
\hline Yaşadığım ilçe ile gurur duyuyorum & $1-5$ \\
\hline Yaşadığım mahalledeki komşularımdan memnunum & $1-5$ \\
\hline Okullarda güvenlik sağlanıyor & $1-5$ \\
\hline $\begin{array}{l}\text { Yaşadığım ilçede boş vaktimi geçireceğim, kendimi geliştireceğim } \\
\text { çok sayıda alternatif programlar mevcut }\end{array}$ & $1-5$ \\
\hline \multicolumn{2}{|l|}{ Kolluk (Jandarma ve Polis) Memnuniyeti } \\
\hline Emniyet personeli yeterli sayıda & $1-5$ \\
\hline Jandarma Personeli yeterli sayıda & $1-5$ \\
\hline Güvenlik yeterli derecede sağlanıyor & $1-5$ \\
\hline Güvenlik personeli nezaketli & $1-5$ \\
\hline Güvenlik birimleri suçu önlemde yeterli & $1-5$ \\
\hline Güvenlik birimleri suçu açığa çıkarmada yeterli & $1-5$ \\
\hline Güvenlik birimleri uyuşturucu ile mücadelede başarılı & $1-5$ \\
\hline
\end{tabular}

Suç Korkusu

Hırsızlık $\quad 0-1$

Gasp $\quad 0-1$

Darp $\quad 0-1$

$\begin{array}{ll}\text { Uyuşturucu madde kullanımı/satı̧ı1 } & 0-1\end{array}$

$\begin{array}{ll}\text { Taciz } & 0-1 \\ & 0-1\end{array}$

Şiddet $\quad 0-1$

$\begin{array}{ll}\text { Teröre maruz kalma } & 0-1\end{array}$

${ }^{68}$ İlgili tablo yazarlar tarafından oluşturulmuştur. 


\section{Bulgular}

\subsection{Betimleyici İstatistikler}

Araştırmanın örneklemini oluşturan bireylerin \%49,3'ü kadın iken \%50,7'si erkektir. Yaş gruplarına göre örneklemin dağılımı incelendiğinde ise, katılımcıların \%16,8'i 18-24 yaş, \%24,3'ü 25-34, \%24,4'ü 35-44, \%18,1'i 45-54 ve \%16,55'i 55 yaş üstü olduğu görülmektedir.

\section{Tablo 2. Katılımcıların Demografik Özellikleri ${ }^{69}$}

\begin{tabular}{|c|c|c|}
\hline Demografik Özellikler & Siklık & Yüzde \\
\hline \multicolumn{3}{|l|}{ Cinsiyet } \\
\hline Kadın & 781 & 49,3 \\
\hline Erkek & 786 & 50,7 \\
\hline \multicolumn{3}{|l|}{ Yaş } \\
\hline $18-24$ & 263 & 16,8 \\
\hline $25-34$ & 381 & 24,3 \\
\hline $35-44$ & 382 & 24,4 \\
\hline $45-54$ & 283 & 18,1 \\
\hline $55+$ & 258 & 16,55 \\
\hline \multicolumn{3}{|l|}{ Eğitim } \\
\hline İlkokul ve altı & 480 & 30,6 \\
\hline Ortaokul & 334 & 21,3 \\
\hline Lise & 504 & 32,2 \\
\hline Üniversite/Lisansüstü & 249 & 15,9 \\
\hline \multicolumn{3}{|l|}{ Medeni Durum } \\
\hline Evli & 1045 & 66,7 \\
\hline Bekâr & 438 & 28 \\
\hline Dul/Boşanmış & 40 & 2,6 \\
\hline Dul/Eşi ölmüş & 37 & 2,4 \\
\hline Birlikte yaşıyor & 7 & 0,4 \\
\hline
\end{tabular}

${ }^{69}$ İlgili tablo yazarlar tarafından oluşturulmuştur. 


\subsection{Bireylerin Güvenlik Algılarn Konusundaki Demografik Farkhllklar}

Bireylerin güvenlik algıları hakkındaki demografik farklılıkları incelemek maksadıyla, güvenlik algısı örtük değişkenin faktör puanları SPSS vasıtasıyla hesaplanmıştır. Shapiro-Wilk normallik testi demografik farklılıkların incelenmesi maksadiyla uygulanacak uygun teste karar verebilmek için yürütülmüştür. Bu testin sonucuna göre faktör puanlarına ait değişken normallik varsayımını karşılayamadığ 1 için $(\mathrm{W}(1567)=0,95$, $\mathrm{p}=0,001)$ non-parametrik testler Kurskal Wallis ve Mann-Whitney U testleri uygulanmıştır.

Tablo 3'de görülebileceği üzere, erkeklerin güvenlik algısı puan ortalaması $(M=867,46)$, kadınların güvenlik algısı ortalamasından $(M=700,01)$ daha yüksektir. Sıra ortalamalarında görülen bu farklılık da istatistiksel olarak anlamlıdır $(\mathrm{U}=241334,5 \mathrm{p}<0,001)$. Erkeklerin kadınlara göre kendilerini daha güvende hissettiklerini gösteren bu sonuçlar Arpa and Uğurlar $^{70}$ tarafından Van ilindeki vatandaşların güvenlik algılarını araştıran çalışmanın sonuçlarını desteklemektedir. Benzer şekilde Boomsma ve Steg ${ }^{71}$ ile Jiang, Mak, Larsen ve Zhong ${ }^{72}$ tarafından yapılan çalışmalar da kadınların güvenlik algısının erkeklere göre düşük olduğunu ortaya koymaktadır.

\section{Tablo 3. Güvenlik Algısının Cinsiyete Göre Mann-Whitney U Testi Sonuçlari ${ }^{73}$}

\begin{tabular}{cccccc}
\hline Grup & N & Sira Ortalaması & Sira Toplamı & U & p \\
\hline Kadın & 781 & 700,01 & 546705,5 & 241334,5 & $0,001^{*}$ \\
Erkek & 786 & 867,46 & 681822,5 & & \\
\hline
\end{tabular}

${ }^{\star} \mathrm{p}<0.001$

\footnotetext{
${ }^{70}$ Arpa ve Uğurlar, a.g.m.

${ }^{71}$ Christine Boomsma ve Linda Steg, "Feeling Safe in the Dark: Examining the Effect of Entrapment, Lighting Levels, and Gender on Feelings of Safety and Lighting Policy Acceptability", Environment and Behavior, Vol. 46, No. 2, 2014, 193-212, s. 193-212.

${ }^{72}$ Bin Jiang, Cecilia Nga Mak vd., "Minimizing the Gender Difference in Perceived Safety: Comparing the Effects of Urban Back Alley Interventions", Fournal of Environmental Psychology, Volume, 51, 2017, 117-131, s. 117-131.

${ }^{73}$ İlgili tablo yazarlar tarafından oluşturulmuştur.
} 
Katılımcıların yaşları beş kategoriye ayrıldığından ve güvenlik algısı örtük değişkenine ait faktör puanları normal dağılım göstermediğinde yaş ve güvenlik algısı arasındaki ilişki Kruskal Wallis testi ile ölçülmüştür. $\mathrm{Bu}$ test sonucuna göre, yaş gruplarının güvenlik algısı ile ilgili olarak anlamlı bir farklılık olduğu görülmektedir $(\mathrm{H}(\mathrm{sd}=4, \mathrm{n}=1567)=11,354$, $\mathrm{p}<0.05$ ) (Tablo 4).

Tablo 4. Güvenlik Algısının Yaş Gruplarına Göre Kruskal-Wallis H Testi Sonuçlari ${ }^{74}$

\begin{tabular}{llcccc}
\hline Yaş Kategorileri & N & Sira Ortalaması & sd & Kruskal-Wallis H & p \\
\hline $18-24$ & 263 & 720.02 & & & \\
$25-34$ & 381 & 757.98 & & & \\
$35-44$ & 382 & 798.54 & 4 & 11,354 & $0,023^{*}$ \\
$45-54$ & 283 & 832.55 & & & \\
$55+$ & 258 & 812.88 & & & \\
\hline
\end{tabular}

${ }^{\star} \mathrm{p}<0.05$

Kruskal-Wallis testi anlamlı çıktığı için yaş kategorileri arasında güvenlik algısı bağlamında bir farklılık olup olmadığını görmek için bir dizi Mann-Whitney U Testleri uygulanmıştır (Tablo 5). Tablo 5'ten de görüleceği üzere 18-24 yaş arasındaki katılımcıların güvenlik algı ortalamaları 35 yaş ve üstü kategorilerde yer alan katılımcılara göre istatistiksel olarak anlamlı şekilde farklılaşmaktadır. Analiz sonuçları 18-24 yaş aralığındaki gençlerimizin güvenlik algılarının düşük olduğunu göstermektedir. Fakat 25-34 yaş grubu katılımcılar 45-54 yaş grubundaki katılımcılara göre kendilerini daha fazla güvende hissetmektedir. Bu sonuç Chadee and Ditton'un $^{75}$ çalışması ile aynı doğrultudadır. Fakat suç korkusu ve

\footnotetext{
${ }^{74}$ İlgili tablo yazarlar tarafından oluşturulmuştur.

${ }^{75}$ Derek Chadee ve Jason Ditton "Are Older People Most Afraid of Crime? Revisiting Ferraro and LaGrange in Trinidad”, British Fournal of Criminology, Vol. 43, No. 2, 2013, 417-433, s. 417-433.
} 
güvenlik algısı çalışmaları yaşlı nüfusun daha yoğun bir güvenlik endişesi taşıdığını ileri sürmektedir. ${ }^{76}$

\section{Tablo 5. Güvenlik Algısının Yaş Gruplarına Göre Mann-Whitney U Testi Sonuçlari ${ }^{77}$}

\begin{tabular}{|c|c|c|c|c|c|}
\hline Grup & $\mathbf{N}$ & Sira Ortalaması & Sıra Toplamı & $\mathbf{U}$ & $\mathbf{p}$ \\
\hline $18-24$ & 263 & 312.13 & 82090.00 & \multirow{2}{*}{47374} & \multirow{2}{*}{0,236} \\
\hline $25-34$ & 381 & 329.66 & 125600.00 & & \\
\hline $18-24$ & 263 & 304.98 & 80210.50 & \multirow{2}{*}{45494.500} & \multirow{2}{*}{$0,040 *$} \\
\hline $35-44$ & 382 & 335.40 & 128124.50 & & \\
\hline $18-24$ & 263 & 253.13 & 66574.00 & \multirow{2}{*}{31858} & \multirow{2}{*}{$0,003 *$} \\
\hline $45-54$ & 283 & 292.43 & 82757.00 & & \\
\hline $18-24$ & 263 & 245.77 & 64637.50 & \multirow{2}{*}{29921.500} & \multirow{2}{*}{$0,019 *$} \\
\hline $55+$ & 258 & 276.53 & 71343.50 & & \\
\hline $25-34$ & 381 & 372.40 & 141886.00 & \multirow{2}{*}{69115.00} & \multirow{2}{*}{0,227} \\
\hline $35-44$ & 382 & 391.57 & 149580.00 & & \\
\hline $25-34$ & 381 & 318.13 & 121209.00 & \multirow{2}{*}{48438} & \multirow{2}{*}{$0,025^{*}$} \\
\hline $45-54$ & 283 & 351.84 & 99571.00 & & \\
\hline $25-34$ & 381 & 310.78 & 118406.50 & \multirow{2}{*}{45635.500} & \multirow{2}{*}{0,122} \\
\hline $55+$ & 258 & 333.62 & 86073.50 & & \\
\hline $45-54$ & 283 & 273.95 & 77528.50 & \multirow{2}{*}{35671.500} & \multirow{2}{*}{0,644} \\
\hline $55+$ & 258 & 267.76 & 69082.50 & & \\
\hline
\end{tabular}

Bireylerin güvenlik algıları ve eğitim durumları arasındaki ilişki incelendiğinde ise, farklı eğitim seviyesindeki bireylerin güvenlik algısı ortalamalarında istatistiksel olarak anlamlı bir fark olmadığ görülmektedir. $\mathrm{H}(\mathrm{sd}=3, \mathrm{n}=1567)=6,683, \mathrm{p}>0.05$ (Tablo 6). Bir diğer deyişle, güvenlik algısı eğitim durumundan bağımsızdır.

\footnotetext{
${ }^{76}$ Randy L. LaGrange, Kenneth F. Ferraro vd. "Perceived Risk and Fear of Crime: Role of Social and Physical Incivilities", Fournal of Research in Crime and Delinquency, Vol. 29, No. 3, 1992, 311-334, s. 311-334.

${ }^{77}$ İlgili tablo yazarlar tarafından oluşturulmuştur.
} 


\section{Tablo 6. Güvenlik Algısı ve Eğitim Durumu Kruskal-Wallis H Testi Sonuçlari ${ }^{78}$}

\begin{tabular}{llccc}
\hline Yaş Kategorileri & N & Sira Ortalaması & Kruskal-Wallis H & p \\
\hline Eğitimsiz/İlkokul mezunu & 480 & 818,79 & & \\
Ortaokul mezunu & 334 & 792,94 & 6,683 & $0,083^{* *}$ \\
Lise mezunu & 504 & 770,14 & & \\
Üniversite/Yüksek Lisans/ Doktora & 249 & 732,99 & & \\
\hline$* * p>0.05$ & & &
\end{tabular}

\subsection{Doğrulayıcı Faktör Analizi}

Analizin ilk aşamasında faktörler tanımlanmıştır. Bu maksatla örtük değişkenler ölçeklendirilmiştir. Araştırmamızda yer alan üç faktöre (çevre memnuniyeti, kolluk memnuniyeti ve güvenlik alg1sı) ait doğrulayıc1 faktör analizine ait sonuçlar Tablo 7 ve 8 'de sunulmuştur. Parametre kestirim yöntemi olarak maksimum olabilirlik yöntemi seçilmiştir. İlk analiz sonucunda faktör yükleri 0,4'ün altında kalan göstergelerin (değişkenlerin) modelden çıkarılması gerekmektedir. ${ }^{79}$ Analiz sonucunda göstergelerimizin tamamı 0,4 barajını aştığı için herhangi bir gösterge ölçeklendirme dış1 bırakılmamıştır. Göstergelerin faktör yüklerinin değerlendirilmesinde, 0,71 ve üstü mükemmel, 0,63 ve 0,70 arası çok iyi, 0,55 ve 0,62 arası iyi ve 0,33 ve 0,44 arası ortalama ve 0,32 'nin altı zayıf olarak kabul edilmektedir. ${ }^{80}$ $\mathrm{Bu}$ kapsamda göstergelere ait faktör yükleyenleri incelendiğinde, çevre memnuniyeti faktörüne yaşanan mahalledeki komşulardan memnuniyet $(0,807)$ ve okullarda güvenliğin sağlanması $(0,757)$ göstergelerinin etkileri mükemmel seviyede iken, diğer iki değişkenin faktöre etkisi ortalama seviyededir. Kolluk (Jandarma ve Polis) memnuniyeti faktörüne ait faktör yükleri incelendiğinde ise, bu faktöre en fazla güvenlik birimleri suçu önlemede yeterlidir $(0,833)$ ve güvenlik birimleri suçu açı̆̆a çıkarmada yeterlidir $(0,810)$ değişkenlerinin etki ettiği görülmektedir (Tablo 7).

\footnotetext{
${ }^{78}$ İlgili tablo yazarlar tarafından oluşturulmuştur.

79 James P. Stevens, Applied multivariate statistics for the social sciences, Routledge, New York, 2012.

${ }^{80}$ Andrew Comrey ve Howerd B. Lee, $A$ first course in factor analysis, Psychology Press, New York, 2013.
} 
Tablo 7. Gösterge Faktör Yükleri ${ }^{81}$

\begin{tabular}{clc}
\hline Faktör & Gösterge & Faktör Yükü \\
\hline Çevre Memnuniyeti & \\
C1 & Çocuk büyütmek için uygun bir yerde yaşıyorum & 0,431 \\
C2 & Yaşadığım ilçe ile gurur duyuyorum & 0,496 \\
C3 & Yaşadığım mahalledeki komşularımdan memnunum & 0,807 \\
C4 & Okullarda güvenlik sağlanıyor & 0,757 \\
C5 & Yaşadığım ilçede boş vaktimi geçireceğim, kendimi geliştireceğim & 0,639 \\
& çok sayıda alternatif programlar mevcut & \\
Kolluk & (Jandarma ve Polis) Memnuniyeti & 0,655 \\
K1 & Emnniyet personeli yeterli sayıda & 0,584 \\
K2 & Jandarma Personeli yeterli sayıda & 0,805 \\
K3 & Güvenlik yeterli derecede sağlanıyor & 0,546 \\
K4 & Güvenlik personeli nezaketli & 0,833 \\
K5 & Güvenlik birimleri suçu önlemde yeterli & 0,810 \\
K6 & Güvenlik birimleri suçu açı̆̆a çıkarmada yeterli & 0,718 \\
K7 & Güvenlik birimleri uyuşturucu ile mücadelede başarılı & \\
Güvenlik Algısı & Gece yalnız başıma sokağa çıkmakta bir tedirginlik görmüyorum & 0,760 \\
G1 & Çocuklarım parkta oynarken tedirgin olmuyorum & 0,703 \\
G2 & Arabamı sokağıma park ettiğimde bir tedirginlik hissetmiyorum & 0,640 \\
G4 & Bir kadın mahallede istediği saatte güvenli bir şekilde yürüyebilir & 0,719 \\
\hline & & \\
\hline
\end{tabular}

Ölçeklerin güvenilirlik ve uygunluk değerleri incelendiğinde ise, ölçeklerin tamamının güvenilirlik derecelerine ait Cronbach alfa değerlerinin standart olarak kabul edilen 0,70 değerinin üzerinde olduğu (çevre algisı = 0,753; kolluk memnuniyeti $=0,881$ ve güvenlik $\operatorname{alg} 1 \mathbf{s} 1=0,798$ ) görülmektedir. Doğrulayıcı faktör analizi sonuçları ölçeklerin uygunluk değerleri ise oldukça iyi seviyede olduğunu ortaya koymaktadır (Tablo 8).

${ }^{81}$ İlgili tablo yazarlar tarafından oluşturulmuştur. 
Güvenlik Algısına Etki Eden Faktörler Üzerine Bir İnceleme

Tablo 8. Ölçeklerin Güvenilirlik ve Uygunluk Değerleri ${ }^{82}$

\begin{tabular}{|c|c|c|c|c|c|c|}
\hline Faktör & $\mathrm{Cmin} / \mathrm{df}$ & GFI & AGFI & CFI & RMSEA & Cronbach- $\alpha$ \\
\hline Çevre memnuniyeti & 4,295 & 0,997 & 0.984 & 0.995 & 0.046 & 0,753 \\
\hline Kolluk Memnuniyeti & 1,966 & 0,996 & 0,990 & 0,998 & 0,25 & 0,881 \\
\hline Güvenlik Algısı & 4,839 & 0,994 & 0,982 & 0.992 & 0.050 & 0,798 \\
\hline
\end{tabular}

Kabul edilen uyumluluk değerleri: $\mathrm{Cmin} / \mathrm{df} \leq 5$; GFI, AGFI ve CFI $>0$; RMSEA $<0,05$

\subsection{Yapısal Eşitlik Analizi}

\section{Model Uyumu}

Bireylerdeki güven algısının yordayıcılarını araştırmak maksadıyla AMOS 26 Graphics analiz yöntemi vasıtasıyla yapısal eşitlik modeli analizi yapılmıştır. Tablo 9'da modele ait uyum iyiliği endeksleri incelendiğinde, değerlerin kabul edilen değerlere uygun olduğu ve dolayısıyla mükemmel bir model uyumu sağlandığı görülmektedir $\left(\chi^{2} / \mathrm{df}=3,93 ; \mathrm{CFI}=0,945 ; \mathrm{RMR}=\right.$ $0,036 ; \mathrm{NFI}=0,928 ; \mathrm{GFI}=0,956 ; \mathrm{AGFI}=0,932 \mathrm{RMSEA}=0,044)$.

\section{Tablo 9. Modele Ait Uyum İyiliği Endeksleri}

Uyum Endeksleri

$\chi^{2} / \mathrm{df}$

The comparative Fit Index (CFI)

Root Mean Square Residual (RMR)

The Normed Fit Index (NFI)

Goodness of Fit Index (GFI)

Adjusted Goodness-of-Fit Index (AGFI)

Root means square error of approximation (RMSEA)
Model

Değerleri

$3,993 \quad \chi^{2} / \mathrm{df} \leq 2, \chi^{2} / \mathrm{df} \leq 5$

$0,945 \quad \mathrm{CFI} \geq 0.90$

$0.036 \quad \mathrm{RMR} \leq 0.05$

$0.928 \quad \mathrm{NFI} \geq 0.90$

$0.956 \quad$ GFI $\geq 0.90$

$0.932 \quad$ AGFI $\geq 0.90$

$0.044 \quad$ RMSEA $\leq 0.055$

${ }^{82}$ İlgili tablo yazarlar tarafından oluşturulmuştur. 
Çevre memnuniyetine etki eden faktörleri tespit etmek amacıyla geliştirilen üç adet hipotez yapısal eşitlik modeli analizi kullanılarak test edilmiştir (Tablo 10). Analiz sonuçları bireylerin çevreleri ile ilgili algıları ve güvenlik algıları arasında istatistiksel olarak anlamlı pozitif bir ilişki olduğunu öne süren birinci hipotezi desteklemektedir. Bu sonuç yaşanılan bölgeden duyulan memnuniyet ve güvenlik algısı arasındaki ilişkinin varlı̆̆ını ortaya koyan önceki çalışma sonuçların ${ }^{83}$ desteklemektedir. Araştırmamızın ikinci hipotezi, kolluk memnuniyeti ile güvenlik algısı arasında pozitif bir ilişki bulunduğunu öne sürmektedir. Yol analizi sonuçları ikinci hipotezimizi desteklemiştir. Benzer şekilde Rinehart Kochel ve Gau'nun ${ }^{84}$ ABD Adalet Bakanlığının St. Louis'de yapmış olduğu sorunlu bölgeler çalışmasının veri seti üzerinde yaptığı çalışma kolluk memnuniyetinin güvende olma algısı üzerinde etkili olduğunu göstermiştir. Torres'in ${ }^{85}$ yaptığ ${ }_{1}$ bir başka araştırma da kolluğun etkinliğinin kolluk memnuniyetini arttırdığını ortaya koymaktadır.

Diğer yandan üçüncü hipotezi (H3: Bireylerin suç korkusu ile güvenlik algıları arasında istatistiksel olarak anlamlı negatif bir ilişki vardır) test etmek maksadıyla 11 suç türüne ait suç korkusu ve güvenlik algısı arasındaki ilişki incelenmiştir. Ancak bu ilişkilerden üç tanesi (uyuşturucu madde ticaretine yönelik suç korkusu, bir terör olayının mağduru olmaya yönelik suç korkusu ve çetelerin tehdit ve taleplerine yönelik suç korkusu) istatistiksel olarak anlamlı çıkmamıştır. Bu nedenle test sonuçlarının üçüncü hipotezi kısmen desteklediğini söylemek mümkündür. Bu sonuç Alda, Bennett, and Morabito'un ${ }^{86}$ bireylerdeki suç korkusu ve kolluk memnuniyeti arasında ters yönlü bir ilişkinin varlığını ortaya koyan çalışması ile uyumludur.

\footnotetext{
${ }^{83}$ Hinkle, a.g.e.; Jiang, a.g.e.; Lapham, a.g.e.

${ }^{84}$ Rinehart Kochel ve Gau, a.g.e.

${ }^{85}$ Torres, a.g.e.,

${ }^{86}$ Eric Alda, Richard R. Bennett vd., "Confidence in the Police and the Fear of Crime in the Developing World", Policing: An International Fournal of Police Strategies $\mathcal{E}$ Management, Vol. 40, No. 2, 2017, 366-379, s. 366-379.
} 
Güvenlik Algısına Etki Eden Faktörler Üzerine Bir İnceleme

Tablo 10. Yol Analizi ${ }^{87}$

\begin{tabular}{|c|c|c|c|c|}
\hline \multicolumn{2}{|c|}{ Hipotezler } & Yol & Standart Katsayı Tahmini & Sonuç \\
\hline & \multicolumn{2}{|c|}{ Çevre memnuniyeti ---> Güvenlik Algısı } & 0,548 & Desteklendi \\
\hline & \multicolumn{2}{|c|}{ Kolluk Memnuniyeti ---> Güvenlik Algısı } & 0,241 & Desteklendi \\
\hline & \multicolumn{2}{|c|}{ Suç Korkusu---> Güvenlik Algısı } & & Desteklendi \\
\hline & 1 & Hırsılzlk ---> Güvenlik Algısı & $-0,084$ & Desteklendi \\
\hline & 2 & Gasp ---> Güvenlik Alg1s1 & $-0,082$ & Desteklendi \\
\hline & 3 & Darp ---> Güvenlik Algısı & $-0,087$ & Desteklendi \\
\hline & 5 & Uyuşturucu Madde Ticareti---> Güvenlik Algısı & $-0,012^{*}$ & Desteklenmedi \\
\hline & 6 & Taciz ---> Güvenlik Algısı & $-0,074$ & Desteklendi \\
\hline & 7 & Şiddet ---> Güvenlik Algısı & $-0,056$ & Desteklendi \\
\hline & 8 & Terör ---> Güvenlik Algısı & $0,08^{*}$ & Desteklenmedi \\
\hline & 9 & Çete---> Güvenlik Algısı & $0,025^{*}$ & Desteklenmedi \\
\hline & 11 & Dolandırıcılık ---> Güvenlik Algıs1 & $-0,091$ & Desteklendi \\
\hline
\end{tabular}

Not: *Standart Katsayı Tahmini $\mathrm{p}<.05$ seviyesinde anlamsızdır.

Çevre memnuniyeti, kolluğa duyulan güven ve suç korkusunun güvenlik algısına etkilerine yönelik analiz sonuçları Şekil-1 ve Tablo 10'da görülmektedir. Bu sonuçlara göre, bireylerin çevreleri hakkındaki algıları güvenlik algılarına en fazla etki eden faktör olarak belirmiştir (standart katsayı tahmini $=0,548$ ). Kolluk memnuniyeti ile güvenlik algısı arasında pozitif yönlü bir ilişki var olup, kolluk hizmetlerine duyulan memnuniyette meydana gelen her 1 birim artış, bireylerin güvenlik algısında 0,241 birim artış meydana gelmektedir (standart katsayı tahmini $=0,241$ ). Suç korkusu ve güvenlik algısı arasındaki ilişki incelendiğinde ise, suç korkusu ve güvenlik algısı arasında negatif yönlü bir ilişki olduğu görülmektedir. En fazla etki yapan suç korkusu unsurlarının, hırsızlık, gasp ve darp suçlarına yönelik suç korkusu olduğu görülmektedir (standart katsayı tahminleri sırasıyla $=-0,084 ;-0,082$ ve $-0,087)$. Ancak, faktör yükleri

${ }^{87}$ İlgili tablo yazarlar tarafından oluşturulmuştur. 
çok düşüktür. Bu durum ise, suç korkusu ile güvenlik algısı arasında zayıf bir bağ olduğunu ortaya koymaktadır.

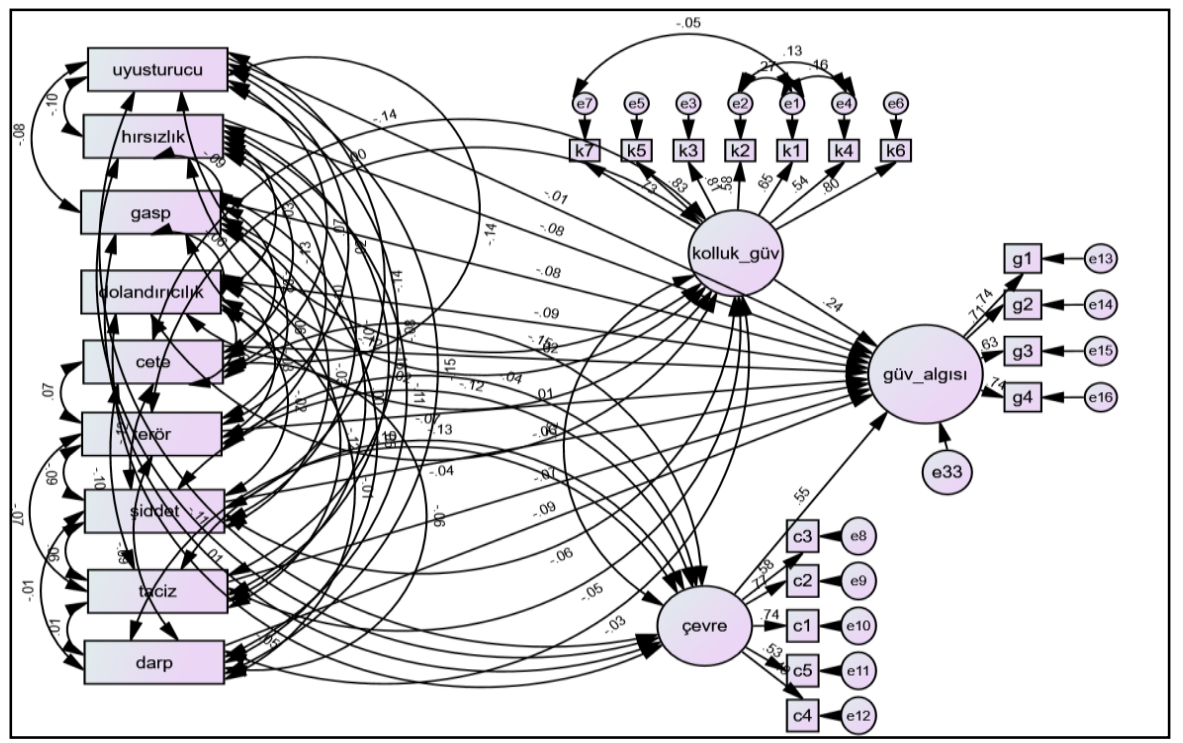

Şekil 2. Yapısal Eşitlik Modeli Analiz Sonucu ${ }^{88}$

\section{Tartışma}

Güvenlik algısı bireylerin sosyal yaşam kaliteleri ve psikolojik bütünlükleri üzerinde önemli etkilere sahiptir. Güvenlik algısına etki eden faktörleri araştıran ampirik çalışmamızın ilk bölümünde demografik değişkenler ile güvenlik algısı arasındaki ikili ilişkiler incelenmiştir. MannWhitney U ve Kruskal Wallis-H testleri cinsiyet, yaş, eğitimi durumu ve güvenlik algısı arasındaki ilişkileri incelemek maksadıyla yapılmıştır. Analiz sonuçları güvenlik algısında cinsiyet farklılıkları bulunduğunu göstermektedir. Mann-Whitney U testi sonuçları erkeklerin kadınlara oranla kendilerini daha fazla güvende hissettikleri göstermektedir. Kadınların bir suçun mağduru olduklarında zaman zaman maruz kaldıkları çoklu mağduriyet güven algısındaki cinsiyet farklılığının önemli nedenlerinden

\footnotetext{
${ }^{88}$ İlgili şekil yazarlar tarafından oluşturulmuştur.
} 
birisi olabilir. Yapılan çalışmalara kadınların hırsızlık gibi suçun mağduru olduktan hemen sonra cinsel bir saldırının da hedefi olduklarını göstermektedir. ${ }^{89}$ Araştırma kapsamında katılımcılara sorulan gece yalnız başına sokağa çıkma ve bir kadının mahallede istediği saatte yalnız başına yürümesi gibi sorular kadın katılımcıların daha yüksek oranda endişe duyduğu cinsel veya fiziksel saldırı riskini işaret etmektedir. Kadınların kendilerini fiziksel bir saldırıya karşı korumada erkeklere göre daha dezavantajlı olmaları da kadınlardaki güvenlik algısının düşük olmasının bir nedeni olarak değerlendirilebilir. Diğer yandan, son dönemlerdeki farkındalık artışıyla toplumsal tepkinin de konusu olan kadına yönelik şiddet olayları ve bu olayların medya sunumları da kadınların kendilerini erkeklere göre daha az güvende hissetmelerine neden olan etmenlerden birisi olarak düşünülebilir.

Güvenlik algısına yönelik yaş farklılıkları incelendiğinde ise, farklı yaş kategorilerinde bulunan vatandaşlarımızın güvenlik algısı kapsamında farklılaştıkları görülmektedir. Analiz sonucuna göre, özellikle 18-24 yaş grubundaki gençlerimiz diğer yaş gruplarına göre kendilerini daha az güvende hissetmektedirler. Hindelang, Gottfredson, and Garofalo'nun ${ }^{90}$ Yaşam Tarzı Teorisi, motive olmuş suçluların daha yoğun olduğu riskli bölgelerde daha fazla zaman harcayan bireylerin veya bu riskli bölgelere yakın alanlarda yaşayan kişilerin mağduriyet riskinin artacağını ön görmektedir. Bu kapsamda, gençlerde güvenlik algısının daha düşük olmasının nedenlerinden birisinin genç nüfusun sosyal hayatta daha aktif olmaları ve suçun daha yoğun olarak işlendiği bölgelerde yaşlı nüfusa göre daha fazla zaman geçirmeleri düşünülebilir. Ayrıca, bireylerin toplum içerisinde kurmuş oldukları sosyal ağların bir çıktısı olan sosyal sermayenin azlı̆̆ da genç bireylerin kendini daha az güvende hissetmelerinin bir nedeni

${ }^{89}$ Lisa Jorgensen, Gary Ellis vd., "Fear Perceptions in Public Parks: Interactions of Environmental Concealment, the Presence of People Recreating, and Gender", Environment and Behavior, Vol. 45,No. 7, 2012, 803-820, s. 803-820; David DeJoy, "An Examination of Gender Differences in Traffic Accident Risk Perception", Accident Analysis E Prevention, Vol. 24, No. 3, 1992, 237-246, s. 237-246; Richard Felson and Patrick Cundiff, "Age and Sexual Assault During Robberies", Evolution and Human Behavior, Vol. 33, No. 1, 2012, 10-16, s. 10-16.

${ }^{90}$ Michael J. Hindelang, Michael R. Gottfredson vd., Victims of Personal Crime: An empirical Foundation for a Theory of Personal Victimization. Cambridge, Ballinger, 1978. 
olabilir. Dallgo ve arkadaşlarının ${ }^{91} 13$ ülkede yapmış oldukları bir araştırma bu önermemizi doğrulamaktadır. Çalışma sonucuna göre, kültürel farklılıklara rağmen sosyal sermayesi daha zayıf olan bireylerin güvenlik algıları diğerlerine göre oldukça düşük çıkmıştır.

Çalışmamızın ikinci bölümünde, çevresel faktörlerin, suç korkusunun ve kolluk memnuniyetinin güvenlik algısı üzerindeki etkileri incelenmiştir. Zimbardo'nun 1969 yılında New York'un gettolarından birisi olan Güney Bronx ve California'nın zengin şehirlerinden Palo Alto'ya plaka numarası yırtılmış ve kapı açık halde bıraktığ 1 iki araca çevredekilerin verecekleri tepkileri ölçmek maksadıyla yapmış olduğu deneyden ${ }^{92}$ esinlenen Wilson ve Kelling gözlemlenen küçük çevresel ve sosyal düzensizliklerin o muhitin suçlulara terk edilmesiyle son bulan bir çöküş sürecini başlattığını öne sürmektedir. ${ }^{93} \mathrm{Bu}$ süreçte informal sosyal kontrol kilit rol oynamaktadır. Bu teoriye göre hem potansiyel suçlular hem de kurallara uyan vatandaşlar bu sosyal ve fiziksel düzensizliklere ait sembollere (toplanmamış çöpler, yıkılmaya yüz tutmuş binalar, sokaklarda gezinen alkolikler veya sokaktaki hayat kadınları vb.) karşı hassastır. ${ }^{94}$ Birinci senaryoda, yasalara uyan vatandaşlar çevredeki artan düzensizlikler nedeniyle güvenli evlerine çekilerek muhitleri ile bağlarını azaltır ve bireyleri yaptıkları küçük kabahatlerden dolayı uyarmaktan çekinirler. Böylece, sosyal kontrol azalır. İkinci durumda ise, fiziksel ve çevresel düzensizlikleri kimsenin umursamadığını, dolayısıyla sosyal kontrolün az olduğunu düşünen potansiyel suçlular daha cüretkâr davranmaya başlar. Muhitte suçların artmasıyla, yerleşikler başka yerlere taşınır ve o bölgeye farklı demografik özelliklere sahip bireyler yerleşmeye başlar. ${ }^{95}$ Her iki senaryoda da artan

\footnotetext{
${ }^{91}$ Dallago vd., a.g.e.,

92 Philip G. Zimbardo, "A Situationist Perspective on the Psychology of Evil: Understanding How Good People are Transformed into Perpetrators", The social psychology of good and evil, (Eds. Arthur Miller), The Guilford Press, New York, 2004.

${ }_{93}$ Wilson ve Kelling, a.g.e.

${ }^{94}$ Jacinta Gau ve Travis Pratt, "Broken Windows or Window Dressing? Citizens' (in)Ability to Tell the Difference between disorder and Crime", Criminology \& Public Policy, Vol. 7, No. 2, 2008, 163-194, s. 163-194; Hinkle ve Yang, a.g.e., 2014.

${ }^{95}$ Robert J. Sampson and Stephen W. Raudenbush, "Seeing Disorder: Neighborhood Stigma and the Social Construction of "Broken Windows"“, Social Psychology Quarterly, Vol. 67, No. 4, 2004, 319-342, s. 319-342; Wesley Skogan, "Broken windows:
} 
çevre memnuniyetsizliği güvenlik algısını olumsuz etkileyerek orada yaşayan insanların yaşam kalitesinde bir düşüşe neden olmaktadır.

$\mathrm{Bu}$ perspektiften hareketle birinci hipotezimiz, bireylerin çevre memnuniyeti ile güvenlik algıları arasında pozitif yönlü bir ilişki olduğunu öne sürmektedir. Çevre memnuniyetini, "çocuk büyütmek için uygun bir yerde yaşıyorum, yaşadığım ilçe ile gurur duyuyorum, yaşadığım mahalledeki komşularımdan memnunum, okullarda güvenlik sağlanıyor ve yaşadığım ilçede boş vakit geçireceğim, kendimi geliştireceğim çok sayıda alternatif programlar mevcut" sorularından oluşan örtük değişken ile ölçülmüştür. Yol analizi sonucumuz, çevre memnuniyeti ile güvenlik algısı arasında pozitif bir ilişkinin varlığını ortaya koymaktadır.

Meşruiyet daha önce de tanımladığımız gibi bir otorite veya kurumun bireylerin ona saygı gösterilme ve itaat etme edilme hakkına sahip olduğunu hissetmelerine neden olan özelliğidir. Kolluk meşruiyeti hem işlevsel hem de normatif boyutları içerir. ${ }^{96}$ İşlevsel modele göre bireylerin yasal makamlarla iş birliği kurma isteği, kolluk performansi, risk ve adaletin dağıtımı hakkındaki algılar ile doğru orantılıdır. Bu yaklaşıma göre kolluk halkın nazarında (i) kuralları çiğneyenler için güvenilir yaptırım tehdidi oluşturduğu (ii) suç ve suçlu davranışını etkili bir şekilde kontrol altına aldığı ve (iii) kolluk hizmetlerini bireyler ve topluluklar arasında adaletli olarak dağıttığı, yönünde algılandığında vatandaşların onayını kazanır. ${ }^{97} \mathrm{Bu}$ yaklaşıma göre kolluğun meşruiyetini kazanması ve idame etmesi kolluğun suçu ve topluluktaki düzensizliği kontrol altına almadaki başarısına bağlıdır. ${ }^{98}$ Diğer yandan, normatif boyut kolluk meşruiyetinin kolluğun karar verme ve yetkilerini kullanmadaki adaleti ve kolluğun davranışlarını ön plana çıkaran usul adaleti kolluğu prensipleri ile elde edilebileceğini savunur. ${ }^{99}$ Normatif bakış açısı, bireylerin müşterek

why-and how-we should take them seriously", Criminology $\mathcal{E}$ Public Policy, Vol. 7, 2008, 195-202, s.195.

96 Lyin Hinds and Kristina Murphy, "Public Satisfaction with Police: Using Procedural Justice to Improve Police Legitimacy", Australian $\mathcal{E}$ New Zealand Fournal of Criminology, Vol. 40, No. 1, 2007, 27-42, s. 27-42.

${ }^{97}$ Sunshine ve Taylor, a.g.e., s. 514.

${ }^{98}$ Hinds ve Murhpy, a.g.e.

${ }^{99}$ Elise Sargeant, Kristina Murphy, vd., "Legitimacy and Policing”, Policing and Security in Practice, (Ed. Tim Prenzler), Palgrave Macmillan UK, Basingstoke, 2007, s. 20-36. 
bir projenin parçası oldukları ve kanunların cezadan kurtulmak için uyulması gereken kurallar olmaktan ziyade toplumun iyiliği için uyulması gereken normlar olduğu inancına dayanır. ${ }^{100}$

Kolluk memnuniyeti örtük değişkeni, “emniyet ve jandarma personel sayılarının yeterli olması, güvenliğin yeterli derecede sağlanması, kolluğun nezaketli olması, güvenlik birimlerinin suçu önlemede, suçu açığa çıkarmada ve uyuşturucu ile mücadelede başarılı olması" ile ölçülmüştür. Güvenlik birimlerinin suçu önlemedeki başarısı $(0,833)$ ve güvenlik birimlerini suçu açığa çıkarmadaki başarısı $(0,810)$ kolluğa duyulan güven değişkenine en fazla etki eden faktörler olarak belirmiştir. Diğer yandan, emniyet ve jandarma personel sayılarının yeterli olması ve personelin nezaketli olması değişkenleri kolluk memnuniyeti örtük değişkenine en az etki eden faktörler olmuştur.

$\mathrm{Bu}$ sonuç işlevsel araçların (kolluğun suçla mücadelesindeki başarısı) kolluk memnuniyetinin oluşmasında normatif araçlara göre daha etkili olduğunu ortaya koyan çalışmalarla ${ }^{101}$ uyumludur. Diğer yandan, usul adaleti yaklaşımını ön gören normatif araçların kolluk memnuniyeti ve meşruiyetinin elde edilmesinde daha başarılı olduğunu belirten araştırma sonuçları ${ }^{102}$ ile çatışmaktadır. Örneğin, Reisig ve Parks ${ }^{103}$ yaptığ kolluk ile yaşanan tecrübe, çevrenin algılanan kalitesi ve muhitin bağlamının (suç oranının yüksek olması veya alt kültür gruplarının varlığı) kolluk memnuniyetini en fazla etkileyen faktörler olduğunu tespit etmiştir. Bağcılar ilçesinde işlevsel araçların (kolluğun suçun önlemede ve suçluları adalet önüne çıkarmadaki başarısı) kolluk memnuniyetini, normatif araçlardan (kolluğun nazik olması) daha fazla etkilemiş olması bu bölgenin suç

\footnotetext{
${ }^{100}$ Eva Moravcová, "Willingness to Cooperate with the Police in four Central European Countries”, European Fournal on Criminal Policy and Research, Vol. 22, No. 1, 2016, 171 187, s. 171-187.

${ }^{101}$ Ben Bradford, Aziz Huq vd., "What Price Fairness When Security is at Stake? Police Legitimacy in South Africa", Regulation E Governance, Vol. 8, No. 2, 2014, 46268; Moravcová, a.g.e.; Tankebe, a.g.e.

${ }^{102}$ Jonathan Jackson, Ian Brunton-Smith vd., "Police Legitimacy and the Norm to Cooperate:Uusing a Mixed Effects Location-Scale Model to Estimate the Strength of Social Norms at a Small Spatial Scale", fournal of Quantitative Criminology, 2020, 1-26, s. 1-26; Tammy Kochel, Roger Parks vd., "Examining Police Effectiveness as a Precursor to Legitimacy and Cooperation with Police", Fustice Quarterly, Vol. 30, No. 5 2013895-925; Tyler, a.g.e.

${ }^{103}$ Reisig and Parks, a.g.e.
} 
oranlarının yüksekliği ve son yıllarda demografik yapısında meydana gelen değişimlerin bir sonucu olduğu düşünülebilir.

\section{Sonuç}

İnsanların en temel ihtiyaçlarından olan ve daha kompleks ihtiyaçlara geçişte kritik öneme haiz olan güvenlik algısı ve onun yordayıcıları suç alanyazınında ilgi çeken konulardan birisi olmasına rağmen ülkemiz yazınında yeterli ilgiyi görmemiştir. Bu çalışma İçişleri Bakanlığı tarafından yapılan önleyici araştırmalar ışı̆̆ında ülkemizin güvenlik alanyazınındaki bu bilgi eksikliğine bir katkı sağlamak ve benzer çalışmaları teşvik etmek maksadıyla dizayn edilmiştir. Kolluk memnuniyeti, çevre memnuniyeti, suç korkusu ve güvenlik algısı arasındaki ilişkileri incelemek amacıyla İstanbul ili Bağcılar ilçesinde yapılan anket çalışması üzerinde yapılan betimleyici ve çok değişkenli istatistik analizleri önemli sonuçlar ortaya koymuştur.

Doğrulayıcı faktör analizi ile her bir faktöre (kolluk memnuniyeti, çevre memnuniyeti ve güvenlik algıs1) etki eden faktörler tespit edilmiştir. Yaşanan muhitten memnuniyet ve okullarda güvenin sağlanması güvenlik algısına en fazla etki eden unsurlar olarak belirmiştir. Çalışmamızın alanyazına önemli bir katkısı ise, işlevsel faktörlerin (güvenlik birimlerinin suç önlemede başarılı olması ve güvenlik birimlerinin suçu açığa çıkarması) normatif faktörlere (kolluğun nezaketli olması ve polis-jandarma personel sayısının yeterli olması) nazaran kolluk memnuniyetine, dolayısıyla güvenlik algısına daha fazla etki ettiğinin tespit edilmesidir. Bu sonuç kolluğun suç önleme ve suçla mücadeledeki başarısının toplumun huzuru ve yaşam kalitesi üzerinde önemli etkileri olduğunu göstermektedir.

Bireylerin güvenlik algısı, "gece yalnız başına sokağa çıkmaktan tedirgin olmamak, çocukları parkta oynarken tedirgin olmamak, arabasını sokağa park ettiğinde tedirgin olmamak ve bir kadının mahallede istediği saatte güvenli bir şekilde yürüyebileceğini” belirten dört farklı boyut ile ölçülmüsstür. Güvenlik algısı ölçeğine ait güvenilirlik analizi sonucu ortaya çıkan Cronbach Alpha $(\alpha)$ değeri $(0,798)$ ölçeğin güvenilirliğinin kabul edilebilir seviyede olduğunu göstermektedir. Araştırmada ikincil veri kullanıldığı için güvenlik algısı mevcut sorularla ölçülmüştür. Gelecekte yapılacak çalışmalarla bu ölçeğe "evdeyken kapının kilitlenmesi, ikametgâha çelik kapı takılması, güvenlik kamerası konulması" gibi yeni boyutlar eklenmesiyle ölçek bireysel güvenlik algısı ekseninde daha fazla geliştirilebilir. 
Yol analizi sonuçlarına göre ise, kolluk memnuniyeti ve çevre memnuniyeti güvenlik algısı ile doğru orantılı bir ilişki söz konusu iken, suç korkusu güvenlik algısı ile ters orantılı bir ilişki ortaya çıkmıştır. Bu faktörlerin güvenlik algısı üzerindeki etkilerine bakıldığında ise, çevre memnuniyeti en fazla etkiye sahip faktör olmuştur. Suç korkusunun ise, güvenlik algısı üzerinde çok zayıf bir etkisi olduğu görülmüştür. Çevre memnuniyetinin kolluk memnuniyetinden güvenlik algısına daha fazla etki etmesinin nedeni çevresel ve sosyal düzensizliklerin daha kolay gözlemleniyor olması çerçevesinde açıklanabilir. Kolluğun suç önleme ve suçla mücadelesindeki başarısı çoğu zaman istatistiklere yansıyan somut rakamlar iken, çevresel düzensizlikler soyut olarak daha yoğun algılanan belirtilerdir. Güvenlik algısının tanımını yaparken belirttiğimiz gibi güvenlik algısı istatistiklerden ziyade bireylerin sezgileri (heuristic) ile alakalıdır. Bu nedenle, kolluğun başta sosyal medya ağları olmak üzere suçla mücadelesindeki başarılarını kamuoyu ile daha yoğun paylaşması kolluk memnuniyetinin güvenlik algısı üzerindeki etkisini arttırabilir.

\section{Summary}

The need of safety, which ranks second in the Maslow's hierarchy of needs after physiological conditions, are prerequisites to meet more advanced needs such as belonging, love, esteem, and self-actualization. Research on perceived safety indicates that perceived safety has a significant impact on the life quality and psychological well-being of individuals. Safety also plays an essential role in reinforcing both social and economic security. In cases where the feeling of insecurity exceeds the acceptable limits, people may have to make radical changes in their lives. For example, the violence caused by organized crime groups in some Central American countries has increased the feeling of insecurity, which led millions of people to migrate to other countries or relocate their homes.

Police legitimacy, known as the right to use power, is another topic examined in the article. Police legitimacy is comprised of two concepts, namely normative and empirical legitimacy. Whereas normative legitimacy can be measured with specific criteria, empirical legitimacy is based on citizens' perception of police. The results of the past research illustrated that the success of police in combatting crime and application of procedural 
policing principles had varying impacts on perceived police legitimacy. In neighborhoods where socially disadvantaged groups live, police legitimacy is affected by the application of procedural policing strategies. Besides this, success in combatting against crime, especially with organized crime, was influential in establishing police legitimacy.

Environmental criminology posits that neighborhood satisfaction has a significant impact on individuals' perceived safety. Social and physical disorganization decrease perceived safety. This perspective suggests that minor physical and social disturbances in the public sphere will incite individuals to commit more serious crimes, and incivilities will increase the fear of crime. Environmental disorganizations such as graffiti, abandoned or demolished buildings were found to affect the perception of security negatively and increase the perceived risk. On the contrary, street cleaning, greening works and environmental improvement activities (opening of parks, gyms and jogging tracks) positively affect individuals' perception of safety.

Lastly, fear of crime and perceived safety are two concepts that are used interchangeably in some research. Perceived security can be broadly defined as a situation, which a person's most essential needs are met, and this is expected to remain stable. In this regard, the perception of insecurity may include threats to individual safety and health and body integrity, or may arise in situations such as crime and disorder. The perceived security is a subjective phenomenon, as it is related to individuals' perception and is often closely associated with situations that require individuals to make a judgement. In other words, it is affected by the context in which events take place. The perception of security encompasses the fear of crime (emotional reaction to danger) as one dimension and the perceived risk (cognitive dimension) as another dimension. Perceived security is more closely related to how individuals interpret events in relevant context rather than statistical data such as crime rates.

Previous research suggests that the perceived safety is a complex phenomenon affected by various factors such as crime rates, physical and social characteristics of the neighborhood, police satisfaction and trust in law enforcement, individual differences, and social capital. This empirical study addresses the knowledge gap regarding factors affecting perceived safety by examining the impact of law enforcement satisfaction (gendarmerie and police), neighborhood satisfaction, fear of crime on perceived safety. To this 
end, the quantitative analyses (Mann-Whitney U, Kruskal Wallis $\mathrm{H}$ and Structural Equation Modelling) of a survey conducted in Istanbul were made. Kruskal Wallis and Mann-Whitney $U$ tests examined the relationship between demographic characteristics of the participants and safety perceptions. The analysis results suggested that females reported feeling more insecure compared to males. This result is in line with the extant research. Regarding the age differences in safety perceptions, participants aged 18-24 reported considerably lower levels of perceived safety than other age groups. This result contradicts previous research depicting that older individuals feel more insecure.

Three hypotheses regarding the effect of neighborhood satisfaction, law enforcement satisfaction, fear of crime on perceived safety were tested through Structural Equation Modelling (SEM). Analysis results supported all three hypotheses. The path analysis indicated that neighborhood satisfaction had a more significant impact on security perception than law enforcement satisfaction. On the other hand, fear of crime had a negligible effect on perceived safety. When these results are interpreted together, it can be inferred that individuals' perceptions related to their social and physical environment are of utmost importance in the formation of perceived safety. Another novel contribution study is documenting that instrumental factors (success in preventing and combatting crime) affect law enforcement satisfaction more significantly than normative factors (kind treatment by law enforcement and the sufficient number of police-gendarmerie personnel).

\section{Çatışma Beyanı:}

Araştırmanın yazarları olarak herhangi bir çıkar çatışma beyanımız bulunmamaktadir.

\section{Destek ve Teşekkür Beyanı:}

Bu çalışmanın hazırlanmasında hiçbir finansmandan yararlanılmamıştır. Çalışmanın hazırlanmasında İçişleri Bakanlı̆̆ İç Güvenlik Stratejileri Dairesi Başkanliğı'nın yürüttü̈̆̈̈ bir araştırma kapsaminda uygulanan bir anket verisinden istifade edilmiştir. Araștırma makalemize esas teşkil eden verinin kullanım izninin verilmesi nedeniyle İcişleri Bakan Yardımcımı Sayın Prof. Dr. Tayyip Sabri ERDIL'e şükranlarımız arz ederiz. 
Güvenlik Algısına Etki Eden Faktörler Üzerine Bir İnceleme

\title{
Araştırmacıların Katkı Oranı Beyanı:
}

Araştırmanin hazırlanmasinda birinci yazarın katkı oranı \%55, ikinci yazarın katkı oranı $\% 45^{\prime}$ tir.

\author{
KAYNAKÇA \\ Kitaplar \\ APPLETON, Jay; The Experience Of Landscape, Wiley, New York, 1996.
}

BYRNE, Barbara M.; Structural Equation Modeling With Amos: Basic Concepts, Applications, And Programming. Routledge, New York, 2016.

COMREY, Andrew And Howard B. Lee; A First Course In Factor Analysis, Psychology Press, New York, (2013).

ELLER, Eric And Dieter Frey; "Psychological Perspectives On Perceived Safety: Social Factors Of Feeling Safe", Perceived Safety: A Multidisciplinary Perspective. Ed. By. Martina Raue, Bernhard Streicher \& Eva Lermer, Cham Springer, 2019.

FERRARO, Kenneth F.; Fear Of Crime: Interpreting Victimization Risk, Albany: State University Of New York Press, 1995.

HINDELANG, Michael J. And Michael R. Gottfredson, Vd.,; Victims Of Personal Crime: An Empirical Foundation For A Theory Of Personal Victimization, Ma: Ballinger, Cambridge, 1978.

JACKSON Jonathan, Bradford Ben Vd. Fust Authority?: Trust In The Police In England And Wales, Routledge, 2012.

RAUE, Martina And Elisabeth Schneider; Psychological Perspectives On Perceived Safety: Zero-Risk Bias, Feelings And Learned Carelessness. Perceived Safety: A Multidisciplinary Perspective. Ed. By. Martina Raue, Bernhard Streicher \& Eva Lermer, Springer, 2019.

SARGEANT Elise, Kristina Murphy Vd.; Legitimacy And Policing. Policing And Security In Practice, Ed. By. Tim Prenzler, Basingstoke: Palgrave Macmillan, Uk, 2012.

STEVENS, James. P.; (2012). Applied Multivariate Statistics For The Social Sciences, Routledge, New York, 2012.

TYLER, Tom R. And Yuen Huo; Trust In The Law: Encouraging Public Cooperation With The Police And Courts, Russell Sage Foundation, New York, 2002.

TYLER, Tom R.; Why People Obey The Law, N.J: Princeton University Press, Princeton, 2006.

ZIMBARDO, Philip. G.; "A Situationist Perspective On The Psychology Of Evil: Understanding How Good People Are Transformed Into Perpetrators", The Social Psychology Of Good And Evil. Ed. By. Arthur Miller, The Guilford Press, New York, 2004.

Makaleler

AFFLECK Rosa T., Kevin Gardner Vd.; "Sustainable Infrastructure In Conflict Zones: Police Facilities' Impact On Perception Of Safety In Afghan Communities", Sustainability, Vol. 11, No. 7, 2019, “1-20”. 
ALDA Eric, Richard R. Bennett Vd.; "Confidence In The Police And The Fear Of Crime In The Developing World”, Policing: An International Fournal Of Police Strategies E Management, Vol. 40, No. 2, 2017, “366-379”.

ALKIMiM Akenya, Keith K. Clarke Vd.; "Fear, Crime, And Space: The Case Of Viçosa, Brazil”, Applied Geography, Vol. 42, 2013, “124-132”.

ARPA, Esra Ve Aysu Uğurlar; "Suç Ve Mekan Bağlaminda Güven Algisi: .Van Örneği”. Yüzüncü Yll Üniversitesi Sosyal Bilimler Enstitüsü Dergisi, No. 44 2019, “293-323”.

BİLEN, Ömer Ve Ali Hakan Büyüklü; "Kırık Pencereler Teorisi'nin İstanbul Metropoliten Alanı'nda Geçerliliğinin Testi”, İdealkent, Sayı 9, Cilt 23, 2018, “160-188”.

BARKWORTH, Julie M. And Kristina Murphy; "Procedural Justice Policing And Citizen Compliance Behaviour: The İmportance Of Emotion", Psychology, Crime E Law, Vol. 21, No. 2, 2015, 254-273.

BOLGER, Michael A. And Colin P. Bolger; "Predicting Fear Of Crime: Results From A Community Survey Of A Small City", American Fournal Of Criminal Fustice, Vol. 44, No. 2, 2019, “334-351".

BOOMSMA, Christine And Linda Steg;"Feeling Safe In The Dark: Examining The Effect Of Entrapment, Lighting Levels, And Gender On Feelings Of Safety And Lighting Policy Acceptability". Environment And Behavior, Vol. 46, No.2, 2014, "193-212".

BRADFORD Ben, Aziz Huq Vd.; "What Price Fairness When Security Is At Stake? Police Legitimacy In South Africa”, Regulation E Governance, Vol. 8, No. 2, 2014 “246-268”.

CANTOR, David; "The New Wave: Forced Displacement Caused By Organized Crime İn Central America And Mexico", Refugee Survey Quarterly, Vol. 33, No. 3, 2014, “34-68”.

CHADEE, Derek And Jason Ditton; "Are Older People Most Afraid Of Crime? Revisiting Ferraro And Lagrange In Trinidad”, British fournal Of Criminology, Vol. 43, No. 2, 2003, “417-433”.

CLAMPET-Lundquist, Susan; "Everyone Had Your Back": Social Ties, Perceived Safety, And Public Housing Relocation, City E Community, Vol. 9, No. 1, 2010, “87-108”.

CURIEL, Rafael Prieto And Steven Bishop; "Modelling The Fear Of Crime", Proceedings Of The Royal Society, Vol. 473, 2017, “1-14”.

DE DONDER, Liesbeth And Nico De Witte Vd.; "Social Capital And Feelings Of Unsafety In Later Life: A Study On The Influence Of Social Networks, Place Attachment, And Civic Participation On Perceived Safety In Belgium", Research On Aging, Vol. 34, No. 4, 2012, “425-448”.

DEJOY, David M.; “An Examination Of Gender Differences In Traffic Accident Risk Perception”, Accident Analysis E Prevention, Vol. 24, No. 3, 1992, “237-246”.

DÖNMEZER, Sulhi; "Hızla Şehirleşen ve Sanayileşen Bir Küçük Şehir Toplumunda Suçluluk (Ereğli Projesi)”, İstanbul Üniversitesi Hukuk Fakültesi Mecmuası, Cilt 39, Sayı $1-4,1974$, , $1-75 "$.

FELSON, Richard B. And Patrick R. Cundiff; "Age And Sexual Assault During Robberies", Evolution And Human Behavior, Vol. 33, No. 1, 2012, "10-16".

FRANK, James And Brad W. Smith Vd.; "Exploring The Basis Of Citizens' Attitudes Toward The Police”. Police Quarterly, Vol. 8, No. 2, 2005, “206-228”.

GAU, Jacinta M. And Travis Pratt; "Broken Windows Or Window Dressing? Citizens'(In) Ability To Tell The Difference Between Disorder And Crime", Criminology E Public Policy, Vol. 7, No. 2, 2008, “163-194”. 
GAU, Jacinta M. And Travis Pratt; "Revisiting Broken Windows Theory: Examining The Sources Of The Discriminant Validity Of Perceived Disorder And Crime", Fournal Of Criminal Fustice, Vol. 38, No. 4, 2010, “758-766”.

GAU, Jacinta M. And Nicholas Corsaro Vd.; "Examining Macro-Level Impacts On Procedural Justice And Police Legitimacy”, Fournal Of Criminal fustice, Vol. 40, No. 4, 2012, “333-343”.

GIBSON, Chris L., Jihong Zhao Vd.; "Social Integration, Individual Perceptions Of Collective Efficacy, And Fear Of Crime In Three Cities”, Fustice Quarterly, Vol. 19, No. 3, 2012, "537-564".

HALE, Chris; "Fear Of Crime: A Review Of The Literatüre", International Review Of Victimology, Vol. 4, 1996, “79-150”.

HILL Jessica, Thomas Pollet Vd.; "Disorder Affects Judgements About A Neighbourhood: Police Presence Does Not", Peerj, Vol.2, No. 1, 2014, “1-18”.

HINDS, Lyin And Kristina Murphy; "Public Satisfaction With Police: Using Procedural Justice To Improve Police Legitimacy”, Australian $\&$ New Zealand Fournal Of Criminology, Vol. 40, No. 1, 2007, “27-42”.

HINKLE, Joshua C.; "Emotional Fear Of Crime Vs. Perceived Safety And Risk: Implications For Measuring "Fear" And Testing The Broken Windows Thesis", American Fournal Of Criminal fustice, Vol. 40, No. 1, 2015, “147-168”.

HINKLE, Joshua C. And David Weisburd; “The Irony Of Broken Windows Policing: A Micro-Place Study Of The Relationship Between Disorder, Focused Police Crackdowns And Fear Of Crime”, fournal Of Criminal fustice, Vol. 36, 2008, "503-512".

HINKLE, Joshua C. And Sue - Ming Yang; "A New Look Into Broken Windows: What Shapes Individuals' Perceptions Of Social Disorder?”, Fournal Of Criminal Fustice, Vol. 42, No. 1, 2014, “26-35”.

KELLING, George; Foot Patrol, Crime File. Study Guide. Washington Dc: National Institute Of Justice, Us Department Of Justice, 2009.

LOEWEN, Laura J., Gary Daniel Steel Vd., "Perceived Safety Fromccrime In The Urban Environment”. Journal Of Environmental Psychology, Vol. 13, No. 4, 1993, “323-331”.

JACKSON Jonathan, Ian Brunton-Smith Vd.; "Police Legitimacy And The Norm To Cooperate: Using A Mixed Effects Location-Scale Model To Estimate The Strength Of Social Norms At A Small Spatial Scale”, Fournal Of Quantitative Criminology, Vol. 37, No. 2, 2020, “1-26”.

JIANG Bin, Cecilia Nga Sze Mak Vd.; "Minimizing The Gender Difference In Perceived Safety: Comparing The Effects Of Urban Back Alley Interventions", Fournal Of Environmental Psychology, Vol. 51, 2017, “117-131”.

JIANG Bin, Cecilia Nga Sze Mak Vd.; "From Broken Windows To Perceived Routine Activities: Examining Impacts Of Environmental Interventions On Perceived Safety Of Urban Alleys", Frontiers In Psychology, Vol. 9, 2018.

JOHNSON, Richard; "Citizen Expectations Of Police Traffic Stop Behavior”, Policing, 27, 2004, “487-497”.

JORGENSEN Lisa, Gray Ellis Vd.; "Fear Perceptions In Public Parks: Interactions Of Environmental Concealment, The Presence Of People Recreating, And Gender", Environment And Behavior, Vol. 45, No. 7, 2013, “803-820".

KOCHEL Tammy, Roger Parks Vd.; "Examining Police Effectiveness As A Precursor To Legitimacy And Cooperation With Police”, fustice Quarterly, Vol. 30, No. 5, 2013, “895-925”. 
KÖSEOĞLU Mualla ve Tülin İçli; "Kadınlarda Suç Korkusunun Çeşitli Değişkenler Açısından Değerlendirilmesi: Kuzey Kıbrıs Örneği”, Sosyal Politika Çalısmalar Dergisi, Cilt 19, Say1 43, 2019, “267- 296”.

LAGRANGE, Randy L. And Kenneth F. Ferraro; “Assessing Age And Gender Differences In Perceived Risk And Fear Of Crime”, Criminology, Vol. 27, No. 4, 1989, “697-720".

LAGRANGE Randy L., Kenneth Ferraro Vd. ; "Perceived Risk And Fear Of Crime: Role Of Social And Physical Incivilities", fournal Of Research In Crime And Delinquency, Vol. 29, No. 3, 1992, “311-334”.

LAPHAM Sandra C., Deborah Cohen Vd.; "How Important Is Perception Of Safety To Park Use? A Four-City Survey”, Urban Studies, Vol. 53, No. 12, 2016, “2624-2636”.

MAZEROLLE Lorraine, Emma Antrobus Vd.; "Shaping Citizen Perceptions Of Police Legitimacy: A Randomized Field Trial Of Procedural Justice”, Criminology, Vol. 51, No. 151, 2013, “33-63”.

MEHTA, Vikas; "Evaluating Public Space”, fournal Of Urban Design, Vol. 19, No. 1, 2014, “53-88".

MILES, Rebecca; "Neighborhood Disorder, Perceived Safety, And Readiness To Encourage Use Of Local Playgrounds", American Fournal Of Preventive Medicine, Vol. 34, No. 4, 2014, “275-281".

MORAVCOVÁ, Eva; "Willingness To Cooperate With The Police In Four Central European Countries”. European fournal On Criminal Policy And Research, Vol. 22, No. 1, 2016, “171-187”.

NOFZIGER, Stacey And Susan, Williams; "Perceptions Of Police And Safety In A Small Town”, Police Quarterly, Vol. 8, No. 2, 2016, “248-270”.

PREACHER, Kristopher J., Zhen, Zhang Vd.; "Alternative Methods For Assessing Mediation In Multilevel Data: The Advantages Of Multilevel Sem", Structural Equation Modeling, Vol. 18, No. 2, 2011, "161-182”.

RATCLIFFE, Jerry H., Elizabeth R. Groff Vd.; “Citizens' Reactions To Hot Spots Policing: Impacts On Perceptions Of Crime, Disorder, Safety And Police”, fournal Of Experimental Criminology, Vol. 11, No. 3, 2015, “393-417”.

REID, Iain D., Sandra Appleby-Arnold Vd.; "Developing A Model Of Perceptions Of Security And Insecurity İn The Context Of Crime", Psychiatry, Psychology And Law, Vol. 27, No. 4, “620-636”.

REISIG, Michael D. And Roger B. Parks; "Satisfaction With Police - What Matters?" Washington, Dc: Us Department Of Fustice, Washington DC, 2002.

RENGIFO, Andres F. And Amanda Bolton; "Routine Activities And Fear Of Crime: Specifying Individual-Level Mechanisms”, European fournal Of Criminology, Vol. 9, No. 2, 2012, “99-119”.

RINEHART Kochel, Tammy And Jacinta Gau; "Examining Police Presence, Tactics, And Engagement As Facilitators Of Informal Social Control In High-Crime Areas", Fustice Quarterly, Vol. 38, No. 2, 2021, “1-21".

RINEHART Kochel, Tammy; "Constructing Hot Spots Policing: Unexamined Consequences For Disadvantaged Populations And For Police Legitimacy", Criminal Fustice Policy Review, Vol. 22, No. 3, “350-374”.

RUIJSBROEK, Annemarie, Mariel Droomers Vd.; "Social Safety, Self-Rated General Health And Physical Activity: Changes In Area Crime, Area Safety Feelings And The Role Of Social Cohesion”, Health E Place, Vol. 31, 2015, “39-45”. 
SAMPSON, Robert J. And Stephen W. Raudenbush; "Seeing Disorder: Neighborhood Stigma And The Social Construction Of "Broken Windows", Social Psychology Quarterly, Vol. 67, No. 4, 2004, “319-342”.

SKOGAN, W. G. (1986). "Fear Of Crime And Neighborhood Change", Crime And Fustice, Vol. 8, 1986, “203-229”.

SKOGAN, Wesley. G.; "Broken Windows: Why-And How-We Should Take Them Seriously”, Criminology \& Pub. Pol’y, Vol. 7, 2008, “195-202”.

SUNSHINE, Jason And Tom R. Tyler; "The Role Of Procedural Justice And Legitimacy In Shaping Public Support For Policing”, Law E Society Review, Vol. 37, No. 3, 2003, “513-548”.

TANKEBE, Justice; "Viewing Things Differently: The Dimensions Of Public Perceptions Of Police Legitimacy”, Criminology, Vol. 1, No. 1, 2013, “103-135”.

TORRES, Jose Alexis; "Predicting Perceived Police Effectiveness In Public Housing: Police Contact, Police Trust, And Police Responsiveness", Policing And Society, Vol. 27, No. 4, 2017, “439-459”.

ULLMAN, Jodie B. And Peter M. Bentler; "Structural Equation Modeling”. Handbook Of Psychology, Vol 2, 2003, “607-634”.

VAN DE VEER, Evelien, Martin A. De Lange Vd.; (2012). "Feelings Of Safety: Ironic Consequences Of Police Patrolling”, fournal Of Applied Social Psychology, Vol. 42, No. 12, 2012, “3114-3125”.

WARNER, Barbara D. And Keri Burchfield; "Misperceived Neighborhood Values And Informal Social Control”, Fustice Quarterly, Vol. 28, No. 4, 2011, “606-630".

WARR, Mark; "Fear Of Crime In The United States: Avenues For Research And Policy”. Criminal Fustice, Vol. 4, No. 4, 2000, “451-489”.

WILSON, James Q. And George L. Kelling; "Broken Windows: The Police And Neighborhood Safety", Atlantic Monthly, Vol. 211, “29-38”.

WINKEL, Frans Willem; "Fear Of Crime And Criminal Victimization: Testing A Theory Of Psychological Incapacitation Of The "Stressor" Based On Downward Comparison Processes”. British Fournal Of Criminology, Vol. 38, No. 3, 1998, “473-484”. ZIMBARDO, Philip G.; "A Situationist Perspective On The Psychology Of Evil: Understanding How Good People Are Transformed Into Perpetrators", The Social Psychology Of Good And Evil. Ed. By. Arthur Miller, The Guilford Press, New York, 2004.

Internet Kaynakları

TDK, “Güvenlik”, 2020. Erişim tarihi: 15 Eylül 2020. https://sozluk.gov.tr/ adresinden erişilmiştir. 